الدهج بين أسلوبى التطريز والإبليك لإثراء أغطية الرأس المستمدة هن

\title{
الزخارف الطبيهية
}

أ/ صباح أحمد حسن مشالى

بكالوريوس التربية النو عية ـ

اقتصاد منزلى - جامعة المنصورة
أ.م.د// إيريني سمير مسيحة داود أستاذ الملابس و النسيج المساعد قسم الإقتصاد المنزلي

كلية التربية النو عية - جامعة طنطا
أ.د/ عادل جمال الدين الهنداوى أستاذ الملابس و النسيج المتفر الاين الماوع قسم الإقتصاد المنزلي لئل

كلبة التربية النو عبة - جامعة طنطا لإلزلي

ملخص البحث

يهدف هذا البحث إلى دراسة الزخارف الطبيعية والاستفادة منها في إثراء أغطية الرأس (الإيشاربات (بإستخدام بقايا الأقمشة بما يتو افق مع منطلبات العصر وذلك بإستخدام الخامات و الألوان

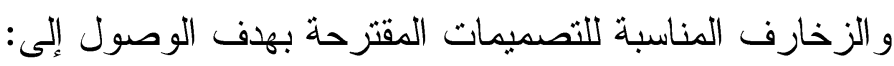
1- أنسب الأقشة المناسبة صحياً لعمل أغطية الر أس.

r- أنسب التصميمات الزخرفية المستمدة من الطبيعة لإثر اء القيم الجماية لأغطية الر أس.

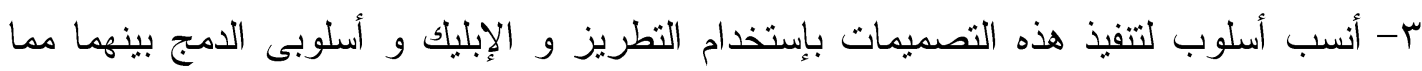
يساهم فى إثر اء أغطية الر أس . ولقد توصل البحث للنتائج التالية:

ا- عدم وجود فروق دالة إحصائياً بين المنتجات عند مستوى (1 (..) وأن المنتج (rv) كان أفضل المنتجات يليه المنتج (9) يليه المنتج (0\%) يليه المنتج (؟). ץ- وجود فروق بين المنتجات المنفذة بالتطريز لإثراء القيم الجمالية لأغطية الرأس (الإيشاربات)

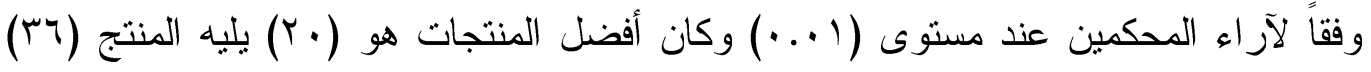
يليه المنتج (9) يليه المنتج (؟). س- وجود فروق بين المنتجات المنفذة بالدمج (النطريز/ الأبليك) لإثراء القيم الجمالية لأغطية

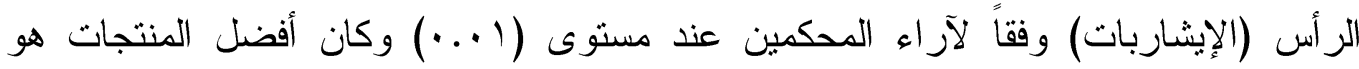

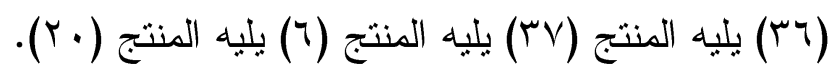

ع - وبالمقارنة بين طرق التنفيذ (الأبليك، التطريز، الدمج، (الأبليك/ التطريز)) للمنتجات نجد أن أسلوب الامج بين (النطريز/ الأبليك) أفضل الطرق للتنفيذ يليه أسلوب التطريز يليه أسلوب الأبليك.

0- جاءت أفضل المنتجات المنفذة هو المنتج (بس) و المنفذ بأسلوب الدمج بين (الأبليك/ النطريز) اليدوي، وأن أقل المنتجات المنفذة هو المنتج (؟) و المنفذ بأسلوبي (النطريز الآلي) - (الأبليك اليدوي) وفقاً لمحاور الثقييم ككل المنتجات المنفذة. 
تطورت صناعات الملابس و النسيج في مصر في الآونة الأخيرة تطوراً كبيراً ويرجع إهنمام

$$
\text { الإنسان بها لأنها تسد حاجة من الحاجات الأساسية للبشر أولا وهي الملبس. }
$$

وقد أدى النطور في الصناعات النسجية إلى ظهور أنواع متعددة ومختلفة من الخامات بما يتلائم مع حاجة المستهلك مع مر اعاة الجو انب الإقتصادية لظروف السوق إلا أن هذا التقدم أغفل جزئياً الإهتمام بالجو انب التي تؤثز سلباً على صحة المستهلك ولقد كان لأغطية الر أس خاصه جانب مما سبق. فأغطية الر أس لها جذور تاريخية في العديد من الحضار ات المختلفة واحتلت مكانة تاريخية في

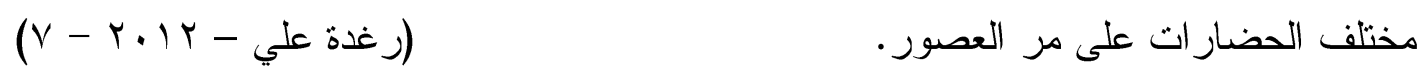
ونظر اً لشيوع إستخدام أغطية الر أس في العصر الحالي فقد برع خبر اء الموضة في إبتكار تصميمات و أثكال وخامات مختلفة لأغطية الر أس إلا أن معظمها منتج من أقمشة ذات ألباف صناعية. و التي لها تأثير سلبيا على صحة المستهلك بصورة متفاونة على المدى البعيد.

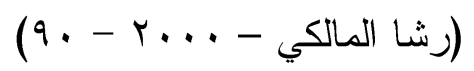

$$
\text { من هنا جاء الاهنمام بموضوع البحث من خلال: }
$$

عمل تصميمات زخرفية لأغطية الر أس مستمدة من زخارف الطبيعة وتنفيذ هذه الزخارف بإستخدام

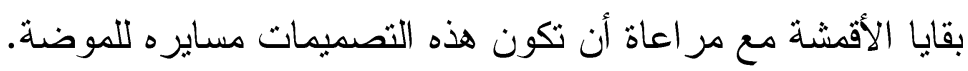
ولكل ما سبق نم اختبار موضوع البحث تحت عنوان (الإستفادة من بقايا الأقمشة لعمل تصميمات زخرفية مستمدة من الطبيعة لإثر اء أغطية الر أس).

مشكلة البحث

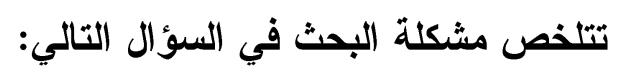
ما إمكانية الإستفادة من بقايا الأقمشة في عمل تصميمات زخرفية لأغطبة الرأس ومستمدة من الطبيعة لإثر اء أغطية الر أس؟ ويتفر ع منه التساؤلات التالية:

1- ما إمكانية إثر اء الجانب الجمالي لأغطية الر أس بإستخدام تصميمات زخرفية مستمدة من الطبيعة؟

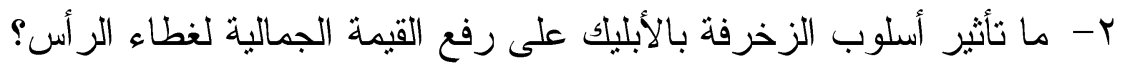

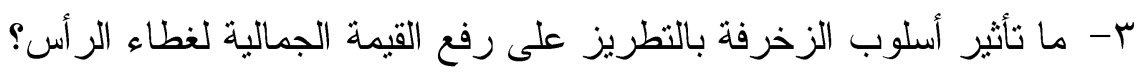
ع- ما تأثير الدمج بين أسلوبي الزخرفة بالتطريز و الأبليك معاً على رفع القيمة الجمالية لغطاء الرأس؟ أسج أهداف البحث

1- التعرف على الأقشة المناسبة صحياً لعمل أغطية الر أس. r- تقديم تصميمات زخرفية مستمدة من الطبيعة لإثر اء القيم الجمالية لأغطية الر أس.

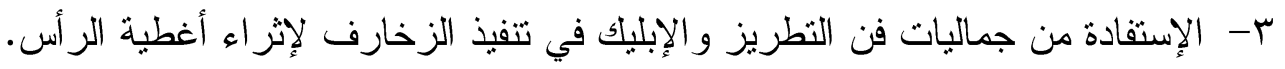

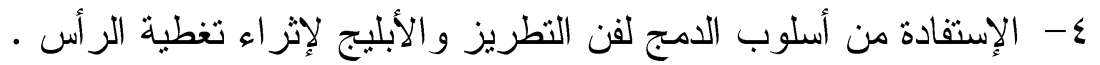




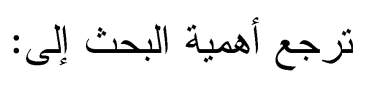

1- إثراء القيم الجمالية لأغطية الر أس المستمدة من الزخارف الطبيعية .

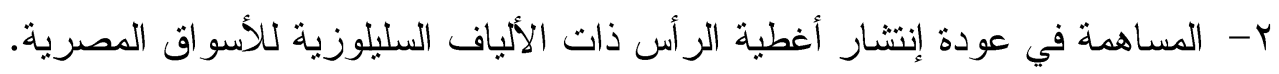
فروض البحث 1- يوجد فرق دال إحصائياً بين نقييمات المحكمين للمنتجات المنفذة والمستوحاة من الوحدات

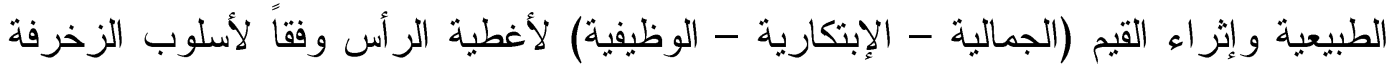

بالأبليك.

ץ- يوجد فرق دال إحصائياً بين تقييمات المحكمين للمنتجات المنفذة والمستوحاة من الوحدات

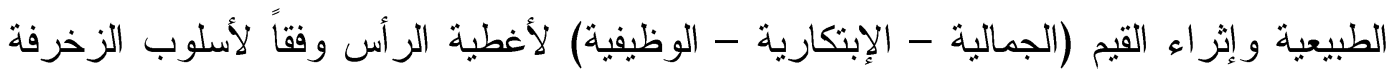

بالتطريز.

r- بوجد فرق دال إحصائياً بين تقييمات المحكمين للمنتجات المنفذة والمسنوحاة من الوحدات

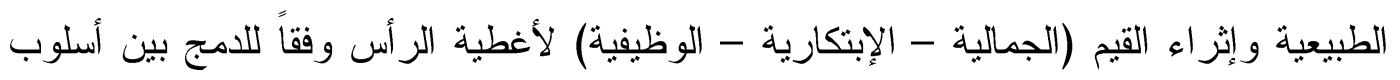
الزخرفة بالتطريز و الأبليك. - مالك. ع- - نوجد فروق ذات دلالة إحصائية بين طرق التنفيذ (الأبليك - النطريز - الامج بين الأبليك و التطريز) للمنتجات المنفذة. ه- توجد فروق ذات دلالة إحصائية بين المنتجات المنفذة بالطرق (الأبليك - التطريز - الامج بين الأبليك و الثطريز ) وفقاً لمتوسط دآ دراء المحمين.

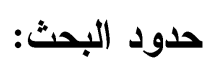
1- عمل تصميمات زخرفية لأغطبة الر أس مستوحاة من الوحدات الطبيعية (نباتية - حيو انية). r- إختلاف أسلوب الزخرفة (النطريز - الأبليك).

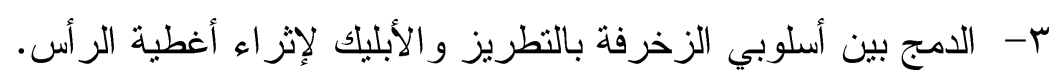

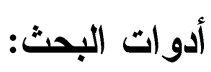
1- الزخارف الطبيعية المتسخدمة لتصميم أغطية الر أس.

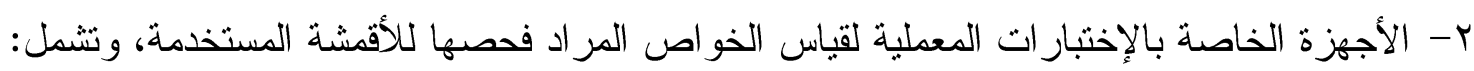
أ- إختبار حرق الأقشة تحت البحث. ب- إختبار وزن المثر المربع للأقششة تحت البعت البحث. ج- إختبار النحليل الكمي الكيميائي لخلطات الألياف. 


$$
\text { منهج البحث } 1 \text { مصطحات البحث ميتع البحث المنهج التجريبي التحليلي لتحقيق فروض البحث. }
$$

تعرف أغطية الرأس على أنها مكملاً هاماً من مكملات الزي الهامة في المجتمع وعبر العصور المختلفة وهو كل ما يغطى رأس المرأة من الشعر و الوجه أو يغطى الشعر أو جزء منه.

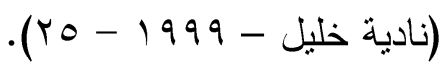

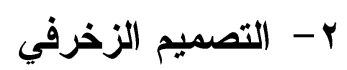

هو ثرجمة لموضوع معين بفكرة مرسومة هادفة لها علاقة تامة بوسيلة التنفيذ وتحمل في جو انبها قيماً ( ثريا نصر - r

$$
\text { ب- الإيشارب: }
$$

هو نوع من أغطية الر أس الذي يمكن إستخدامه بأساليب عديدة ويتخذ جميع الألوان السادة أو المطبوع بزخارف متتوعة ومنها ما يكون مطرزاً ومنها ما يدخل في صناعته الخيوط المعدنية ويأخذ شكل

$$
\begin{aligned}
& \text { (نادية خليل - 1999 - (نو ) } \\
& \text { المربع أو المثلث أو المستطيل. } \\
& \text { צ- الأبليك: (Appliques) }
\end{aligned}
$$

هو إضافة قطع صغيرة من الأفمشة إلى مساحات أخرى مختلفة عنها في اللون أو نوعية الخامة وتكون

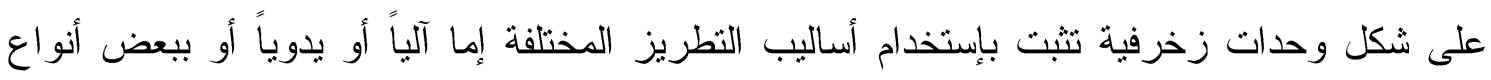

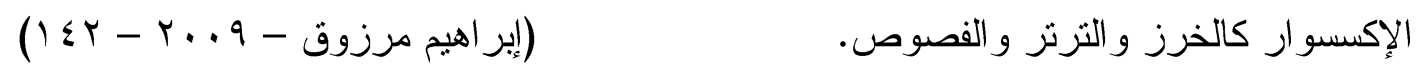

الار اسات السابقة المرتبطة بموضوع البحث دراسات تناولت أغطبة الر أس:

ا- دراسة رشا محمد محمد المالكي (....... - "در) اسة بعض الخواص المختلفة للخامات المستخدمة في إنتاج أغطية الر أس للنساء ومدى ثأثير ها في تفادى المشكلات الصحية". هدفت الدر اسة إلى : - إس 1- التعرف على التطور التاريخي لأغطية الر أس. r- التعرف على أهم الأمر اض الجلدية التي تصيب الجلد و الشعر . ب- تحديد أهم معايير التفضيل الشرائية لدى المستهلك. 


\section{الإجراءات التجريبية لهذه الاراسة:}

تم عمل مجموعة من التجارب العملية على عينات من أغطية الرأس المستخدمة بالأسواق من خامات مختلفة للتعرف على المواصفات الفعلية لهذه العينات والتعرف على خواصها الطبيعية

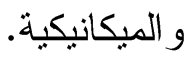
وتوصلت الدراسة إلى: 1- وجود علاقة بين عدد سنوات إرتداء الإيشارب وظهور بعض الأعر اض الجلدية.

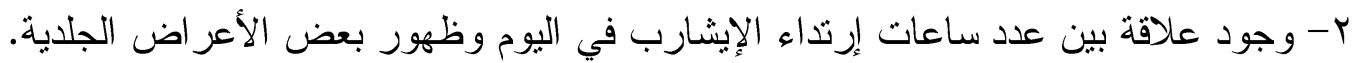

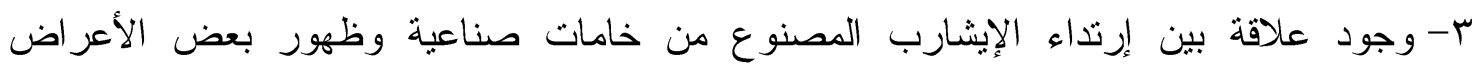

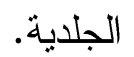
أوجه الإستفادة من هذه الدر اسة: التعرف على بعض الأعراض الجلدية التي تسبيها أغطية الرأس المنتجة من الخامات الصناعية و أهمية إرتداء أغطية رأس منتجة من ألياف طبيعية

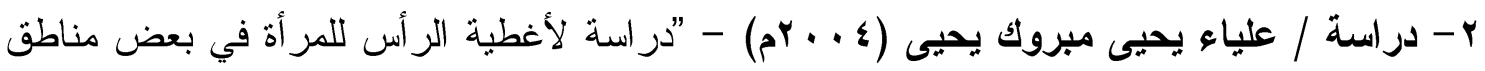

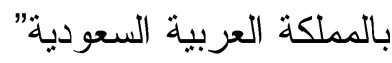

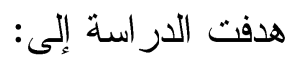

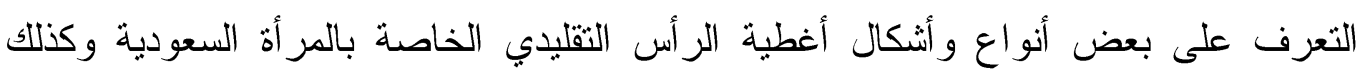
تسجيل وتوثيق هذا الجزء من تر اثنا الثعبي للحفاظ عليه من الإندثار. الإجر اءات التجريبية لهذه الدر استة: تم عمل مجموعة من التصميمات ذات أنواع وأشكال مختلفة لأغطية الر أس بناء على نتائج الار اسة وتقييمها من مجمو عة من المحكمين المتخصصين.

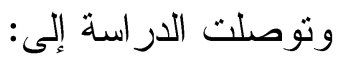

أن أغطية الرأس الخاصة بالنساء في أنحاء المملكة العربية السعودية تتوعت وتعددت و إستمر

$$
\text { وأوجه الإستفادة من هذه الآن ولكن مع شيء من التبسيط. }
$$

أن توثيق التزاث الثعبي الخاص بأغطية الرأس عبر العصور بساهم بشكل كبير في تطورها

و إبتكار تصميمات جديدة تتلاءم مع منطلبات العصر الحالي.

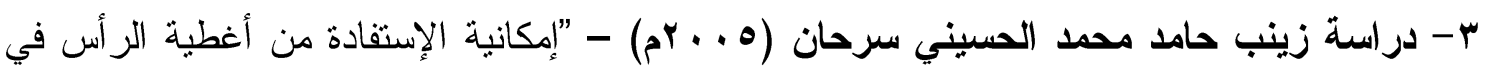
العصور الإسلامية في إبتكار تصميمات عصرية لطالبات الجامعة".

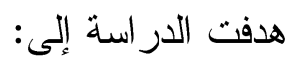
التعرف على القيم الفنية والجمالية للتراث الإسلامي وإستحداث تصميمات زخرفية منتوعة لإلثر اء أغطية الر أس بما يتناسب مع طالبات الجامعة. 
الإجراعات التجريبية لهذه الار اسة:

ا- تم إستخدام · r تصميم زخرفي مستحدث من الفنون و الزخارف الإسلامية ثم توظيف هذه

الوحدات على غطاء الر أس.

ץ- ثم عمل مجموعة من التصميمات لطرق إرتداء أغطية الر أس لتتاسب مرحلة طلاب الجامعة.

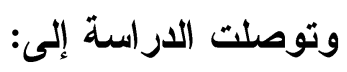

1- تصميم أغطية رأس ذات طابع إسلامي تنتاسب مع طالبات الجامعة.

r- الوصول إلى إبتكار طرق جديده لإزتداء غطاء الر أس.

أوجه الإستفادة من هذه الدر اسة:

التعرف على طرق مبتكرة لإزثداء أغطية الرأس تثتاسب مع مجتمعنا الإسلامي وكيفية إستحداث تصميمات زخرفية متتو عة.

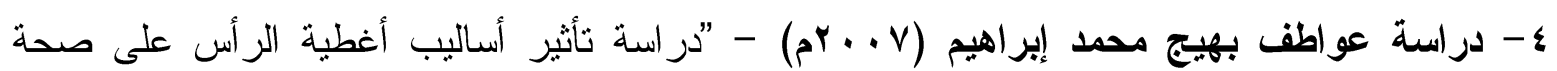
المر أة"

هدفت الار اسة إلى : ماه:

التعرف على الأساليب المختلفة لإرتداء أغطية الر أس للمر أة و العو امل التي تؤثر على إختيارها وكذلك التعرف على الآثار الصحية الناتجة عن إستخدام هذه الأساليب.

الإجراعات التجريبية لهذه الدراسة:

تم تتفيذ مجموعة تصميمات لأغطية الر أس بناء على نتائج الدراسة ووفقاً لأكثر الأساليب الشائعة في إرتداء غطاء الر أس وكذلك العو امل المؤثزة على إختيارها والأثار الصحية السلبية المترتبة عليها. وتوصلت الار اسة إلى:

وجود علاقة إرتباطية بين الأساليب المختلفة لإرتداء المرأة لأغطية الرأس و العوامل المؤثزة على إختبار ها من جهة وبين الآثار الصحية السلبية المترتبة على ذلك من جهة أخرى. أوجه الإستفادة من هذه الدر اسة:

التعرف على أفضل أساليب إرتداء أغطية الر أس و أقلها تأثثر ا على صحة المر أة. ه- دراسة / يسرى معوض عيسى أحمد (V) . . r م) - "عنصر النبات كمصدر لإثز اء التصميمات

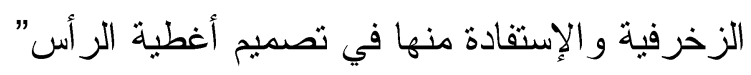

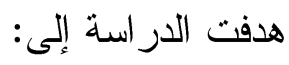

1- تحليل و إستخدام الوحدات النشكيلية المأخوذة من عنصر النبات و الناتجة عن زاويتي الرؤية الأفقية و الر أسية وإستخدامها في زخرفة وتصميم أغطية الر أس (الإيشاربات) من خلال الطباعة

$$
\text { وبعض أساليب الثطريز }
$$


ץ- رفع مستوى الحس الفني وثوضيح الجوانب الكامنة والقيمة الفنية لعنصر النبات لكونه مصدر هام من مصادر الإلهام للمصمح و الفنان. الإجر اءات التجريبية لهذه الدراسة:

تم إستخدام مجموعة من التصميمات الزخرفية المستمدة من العناصر النباتية ثم توظيف هذه الوحدات على غطاء الرأس. وتوصلت الدر اسة إلى:

1- يوجد فروف داله إحصائياً بين الأسس الإنشائية المستخدمة في التصميمات الزخرفية. ץ- هناك إختلاف في درجة مساهمة الأسس الإنشائية على التصميمات الزخرفية. أوجه الإستفادة من هذه الدر اسة: الإستفادة من إحدى عناصر الطبيعة في عمل تصميمات زخرفية لأغطية الر أس.

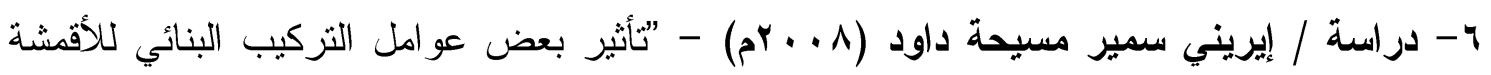

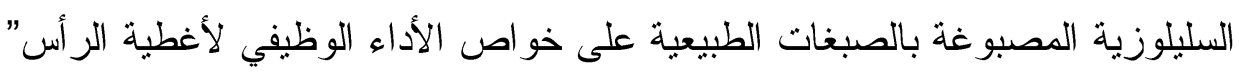
هدفت الدر اسة إلى:

1- التعرف على أنسب نوع خامة للأقمشة السليلوزية و التي تحقق أعلى قيمة لعمق اللون. r- الكشف عن أنسب نوع صبغة طبيعية لأفضل خامة مستخدمة تعطى أفضل خو اص طبيعية و وميكانيكية للأقمشة المنتجة.

r- الوصول لأنسب نوع صبغة طبيعية من حيث خو اص الثبات. الإجر اءات التجريبية لهذه الدر اسة: نم إنتاج أقمشة البحث وفقا للعو امل النسجية التالية: 1- العو امل النسجية الثابتة: إستخدمت الأقشة السيليلوزية بالمواصفات الثالية (التركيب النسجي

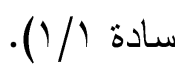

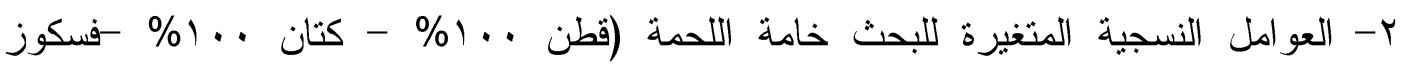

$$
(\%) \text {.. }
$$

ولقد تم إستخدام ثلاثة من الصبغات الطبيعية (كركم - كركديه - قشر الرمان) لعينات البحث بنسبة . . . مل من مخلوط الصبغة / ه جم قماش.

$$
\text { وتوصلت الدر اسة إلى: }
$$

1- أن أفضل خامة تحقق أفضل خو اص الأداء الوظيفي هي المخلوط (قطن / فسكوز) بإستخدام لحمة ع 1/ ا و مصبو غة بصبغة الكركدية. 
r- أن أفضل خامة تحقق أفضل خواص الأداء الوظيفي هي خامة المخلوط (قطن / فسكوز) بإستخدام لحمة 1/11 قطن إنجليزي ومصبو غة بصبغات (الكركم - قشر الرمان).

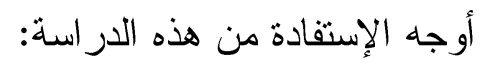

إمكانية التعرف على أفضل خواص الأداء الوظيفي لأغطية الرأس المنتجة من الخامات

السيليلزية المصبوغة بالصفات الطبيعية.

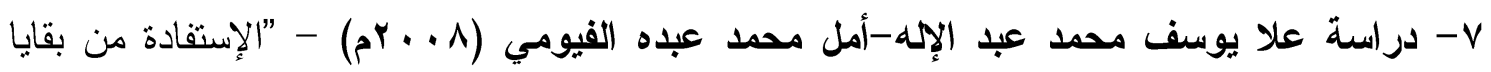

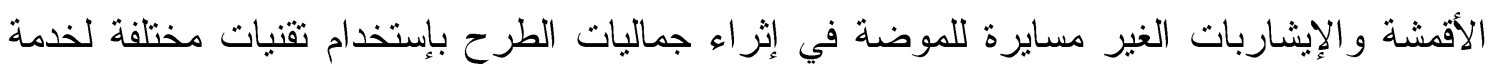

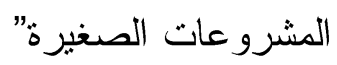

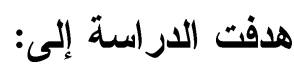

الكثف عن الإستفادة من الطرح و الإيشاربات الغير مسايرة للموضة وبقايا الأقمشة في عمل الطئل

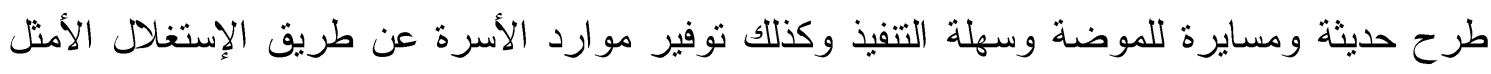

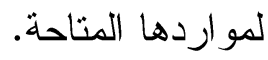
الإجر اءات التجريبية لهذه الدر اسة:

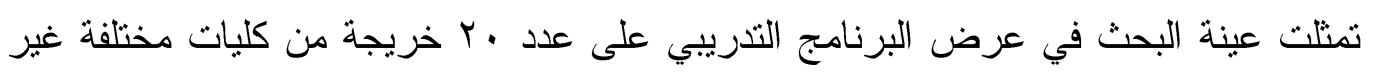

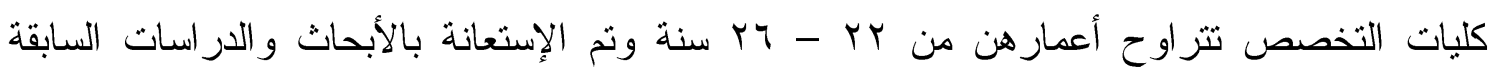

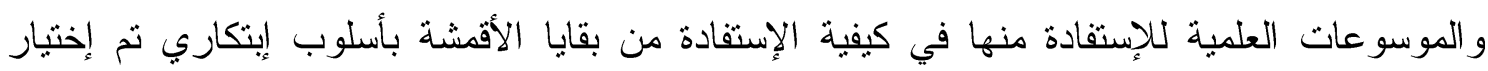
أسلوب (البيان العملي) لأنه الأمثل لتعلم هذه الفئة.

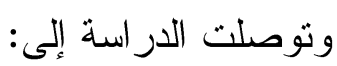
وجود فروق ذات دلالة إحصائية بين تقنية قص الإيشاربات وبين تقنيات التصميمات المنفذة. أوجه الإستفادة من هذه الدراسة:

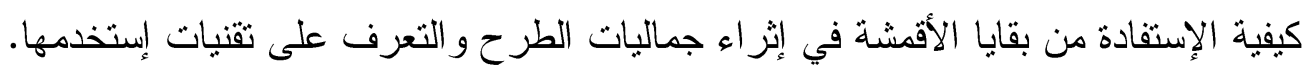

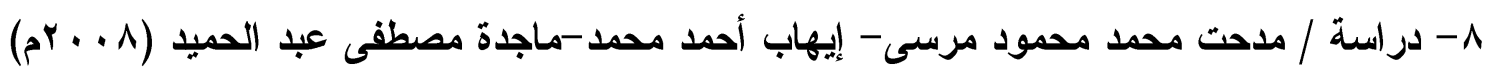

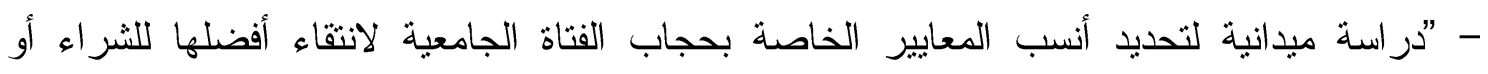

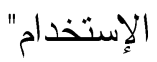

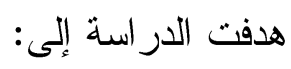
التعرف على أهم معايير التفضيل الثر ائية لاى المستهلك. الإجر اءات التجريبية لهذه الدراسة:

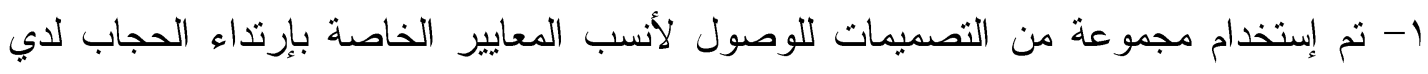

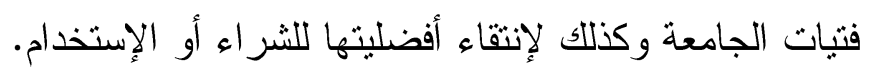


ץ- نم تتفيذ مجموعة مختلفة من تصميمات أغطية الر أس من خامات مختلفة للوصول إلى أفضل نوع خامة ذو تأثنير أقل على الصحة. وتوصلت الدر اسة إلى : بلى

1-نوجد علاقة ذات دلالة إحصائية بين طول فترة إرتداء الحجاب (الإيشارب) وبين ظهور مشكلات جلدية بالنسبة لعدد الساعات في اليوم و عدد السنوات في العمر . r- توجد علاقة ذات دلالة إحصائية بين نوع الخامة المصنع منها الحجاب (الإيشارب) وبين ظهور بعض الآثار الصحية على الفتاة الجامعية. أوجه الإستفادة من هذه الدر اسة:

التعرف على أفضل الخامات الملائمة صحيا لإنتاج أغطية الر أس وكذلك التعرف على معايير التفضيل الشر ائية لدى المستهلك. 9- در اسة إيمان محمد مصطفى غانم (Y I r م) - "در اسة المنطلبات الوظيفية لنصميم أغطية الر أس للسيدات" هدفت الدر اسة إلى : م إلى التعرف على القيم الوظيفية و الجمالية لأغطية الر أس ومدى ملاعمنها للإستخدام لاى السيدات. الإجر اءات التجريبية لهذه الدر اسة: بناءً على الدراسات السابقة تم الوصول لتحديد أفضل الخامات الملائمة لأغطية الرأس وتم عمل مجموعة من التصميمات المختلفة روعي فيها نطبيق منطلبات التصميم ونم تتفيذها بناء على نتائج الدر اسة وتم تقييمها من مجمو عة من المحكمين المتخصصين. وتوصلت الدر اسة إلى:

إبتكار تصميمات جديدة تتلاءم مع الإحتياجات الوظيفية لأغطية الر أس للسيدات. أوجه الإستفادة من هذه الدر اسة:

مدى ملائمة غطاء الر أس للمتطلبات الوظيفية و الر احة الملبسية المر اد تحقيقها. • 1 - دراسة رغده مختار سيد مصطفى محمد على (r I . r م) - "غطاء رأس السيدات كأحد مكملات الزى در اسة تاريخية تطبيقية" هدفت الدر اسة إلى : مأى 1- التعرف على التطور التاريخي لغطاء الرأس عبر العصور المختلفة وعلاقته بمفردات الأزياء. ץ- التعرف على آر اء شر ائح من المجتمع من متطلبات غطاء الر أس لعمل تصميمات تتاسب العصر عرد الحالي.

r- إستخدام غطاء الر أس بطرق مختلفة وتصميمات متتوعة لبناسب تفضيلات المر أة المصرية. الإجر اعات التجريبية لهذه الدر اسة: 
تم تتفيذ مجموعة تصميمات لأغطية الرأس بناء على أعلى نسبة مئوية لونية وجمالية تم

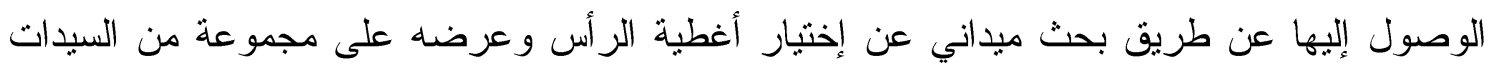
للوصول إلى نتائج تقوم عليها عملية الإبنكار وتصميم الأزياء.

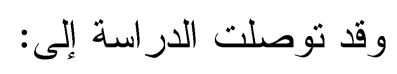

1- وجود علاقة بين طرز أغطية الر أس وبين العو امل الثقافية والإجتماعية و السياسية عبر العصور .

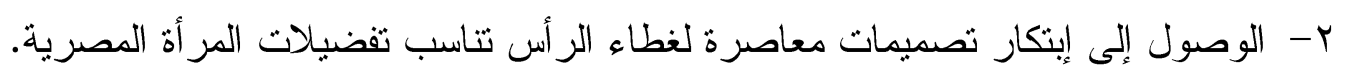

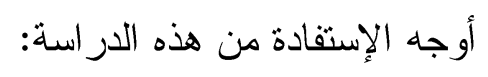

التعرف على طرز أغطية الرأس عبر العصور ومعرفة العوامل التي تؤثر على تحديد شكل

$$
\text { ولون و أسلوب الإرتداء لغطاء الر أس. }
$$

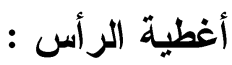

تعتبر أغطية الر أس من أهم مكملات الزي وهي اللمسة الأخيرة التي بدونها لا يكتمل المظهر

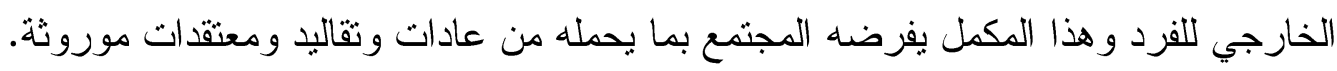

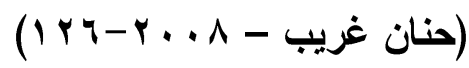

وبالنظر لأغطية الرأس في العصور المختلفة فإننا نجدها ترجمة صريحة لأحاسيس المر أة تجاه

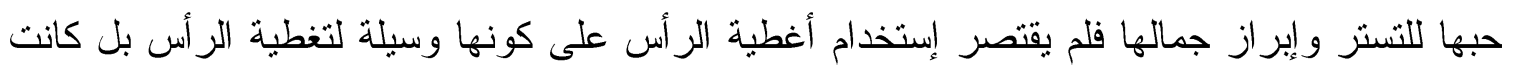

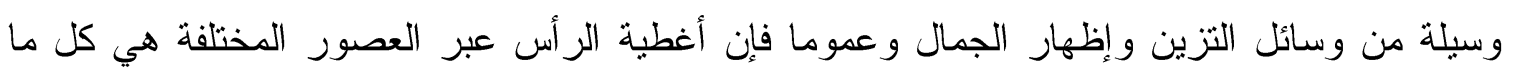

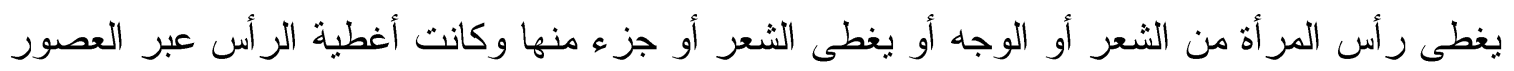

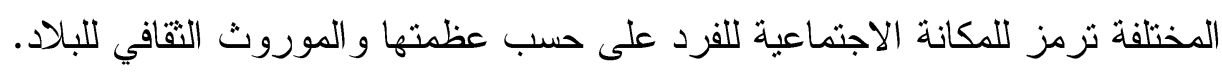

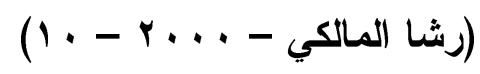

ويتم تصنيف أغطية الرأس تبعا للمساحة التي تغطيها من العضو إلى:

1- أغطية تستر جزء من الثعر فقط مثل الطاقية و المنديل . r- أغطية تستر الثعر كله مثل الطرحة و الإيشارب.

r- أغطية تستر الشعر و الأذن فقط مثل الطاقية و المنديل و العصابة.

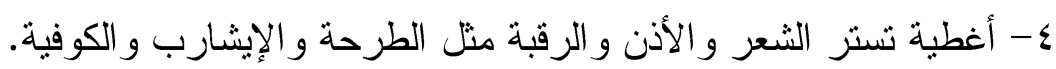

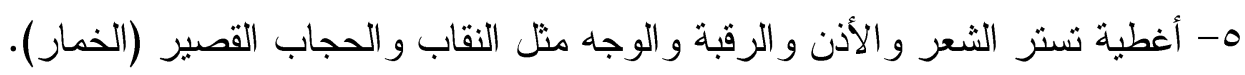

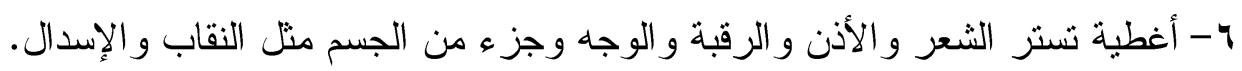

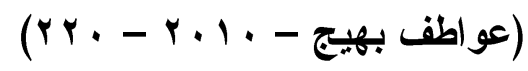


الأقمشة المناسبة صحيا لعمل أغطية الر أس:

ا. يفضل إستخدام الأقمشة الطبيعية أو الصناعية ذات أصل طبيعي لعمل أغطية الر أس وذلك لتفادى العديد من الأعر اض والأمر اض الناتجة عن ارتداء أغطية الرأس المنتجة من الألياف الصناعية

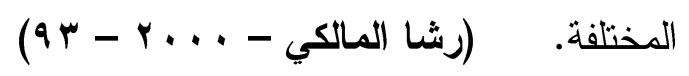

r. ومن أمثلة الأقمشة المناسبة صحيا لعمل أغطية الر أس:

$$
\text { r. أقششة (القطن - الفسكوز - الكتان - الحرير الطبيعى) }
$$

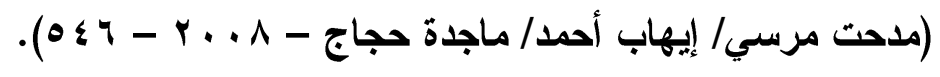

الألياف النسجية المستخدمة في البحث:

أولا : القطن:

يعتبر القطن من أقدم الألياف التي استخدمها الإنسان و أكبر إنتاج في الألياف جميعها حيث يستهلك العالم من ألياف القطن ضعف ما بيتهلاك من الألياف الأخرى، كما بعتبر القطن من أهم مصادر الألياف الطبيعية إستخداماً حيث بحتل المركز الرئيسي بين الألياف في صناعة المنسوجات وفى كساء الإنسان. (Joseph, Marjory ,1980 - p. 68)

$$
\begin{aligned}
& \text { ويتكون القطن مـن مادة السليلوز التي تتراوح نسبتها في القطن الخام بين rیر: 90\% }
\end{aligned}
$$

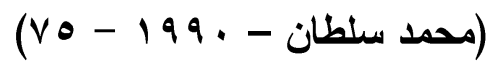

مميزات الأقمشة القطنية:

1- ثتميز الأقمشة القطنية بأنها مريحة في الإستعمال ولا تسبب أي مضايقات للجسم حيث ثمتص

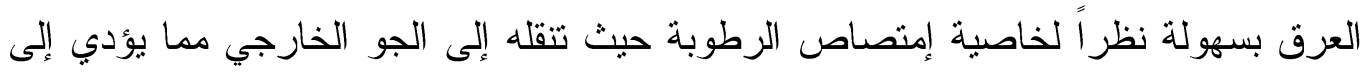

$$
\text { الإحساس بالر احة. }
$$

r- تتحمل الأقشة القطنية عمليات الغسيل المتكررة لمدة طويلة عند درجة غليان الماء دون التأثز

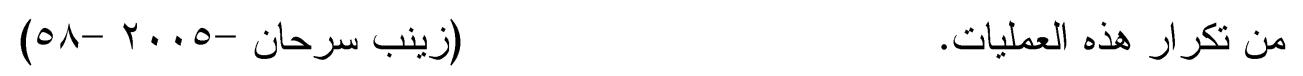

ب- يمتاز القطن بقلة الشحنات الكهربائية المتولدة من الإحتكالك وهذا يقلل من قابلية الأقمشة

$$
\begin{aligned}
& \text { لإلتشاخ. }
\end{aligned}
$$

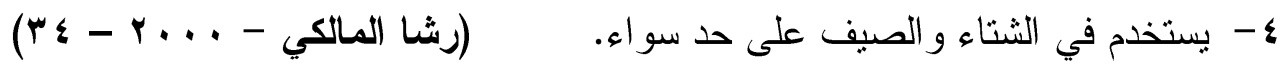

ه- يتميز القطن بالمرونة العالية وذلك نتيجة لإرتفاع نسبة السليلوز به بجانب نسبة الإسنطالة

$$
\text { المقبولة مما يساعد على مقاومة الأقمشة على الإستهلاك. بالك. }
$$

צ- تزداد مثانة الأقمشة القطنية عند البلل عنها وهي جافة وهذه المنانة تختلف حسب رنبة القطن و هذه الخاصية من أهم الخو اص التي تدعم مركز الملابس القطنية بالنسبة للألياف الصناعية.

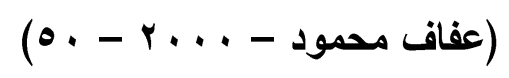


ثانيا : رايون الفسكوز:

يعتبر رايون الفسكوز أول أنواع الألياف الصناعية التي أنتجت من السليلوز وذللك بتحويل السليلوز الغير قابل للذوبان أو الإنصهار إلى شكل قابل للذوبان ويتم إنتاج ويتم إنتاج ألياف الر ايون من السليلوز على عدة مراحل ثبدأ بمرحلة إستخراج السليلوز النقي من الخشب وذللك بمعالجة الخشب الإنب بمحلول هبدروكسيد الصوديوم ثم ثبيض الناتج ثم إز الة أي آنار للعناصر المعدنية.

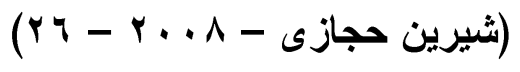

عيوب الألياف الصناعية: بالبحث في العديد من الأسواق المصرية وجدت الباحثة أن أغلب أغطية الرأس المطروحة في الأسواق المصرية منتج من ألياف صناعية خالصة والتي لها العديد من الأضر ار على صحة المستهلك

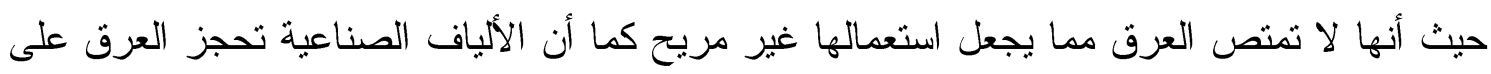
الجلد بالإضافة إلى أن الألياف الصناعية تحتفظ بالثحناث الكهربائية الساكنة على سطح النسيج. كما تؤدي ظاهرة الكهرباء الإستاتيكية إلى تلاصف الملابس، و الإتساخ الدائم للملابس وحدوث

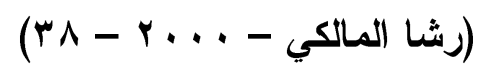
الطقطقة و الثرارة. وفى دراسة لاكتور أحمد شفيق لدراسة تأثثر الأنواع المختلفة من الأقمشة على نمو الشعر أظهرت النتائج أن البولى إستر له نأثير كبير على عدم نمو الشعر نتيجة لتولد الشحنات الكهربائية التي تتتج من إحتكالك البولى إستر بالجلد مما يولد الشحنات التي تعمل على تحوصل بصيلة الشعر وعدم (Shafik-A -1993-P,239) نموه. كما يؤدى إرتداء الإيشارب المصنوع من خامات مخلوطة إلى ظهور الحكة الجلدية و إحمر ار الجلد.

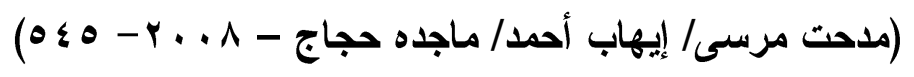

وفى دراسة ميدانية لــ Lesleil و آخرون مستخدماً فيها إستبيان على عينة من الأفر اد أبرزت نتائجها أن الإحتكاك الناشئ عن تلامس الأنسجة و الملابس للجلد يؤدى إلى ظهور بعض المشكلات الصحية والأمر اض الجلدية مثل ثهيج الجلد وبعض مشاكل الجهاز التنفسى مثل إحتقان - عطس ورشح إضافة إلى مشاكل العيون مثل مياه العين Watery Eyes، إنتفاخ العين Eye Swelling

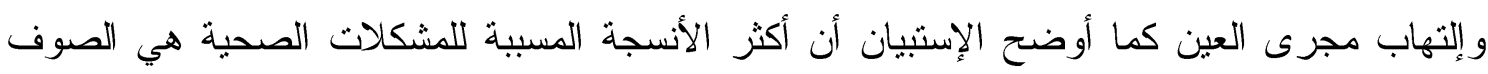
(Lesleil, Nacy, Merry Jo, 1990 - P. 311-322) يليه البولى إستر ثم النايلون.

الإختبار ات المعملية والتجارب والعملية

تم عمل إختبار ات معملية للأقمشة المستخدمة في الدر اسة لمعرفة نوع الخامة و اختبار الطبيعية منها أو التي تحتوي على نسبة خلط عالية من الألباف الطبيعية حتى تتتاسب مع الغرض الوظيفي نوع لأغطية الر أس. 
الإختبارات المعلية التي تم إجراؤها على الأقشة المستخدمة في البحث:

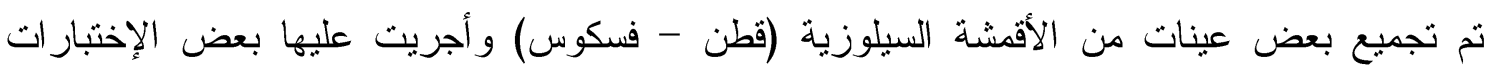

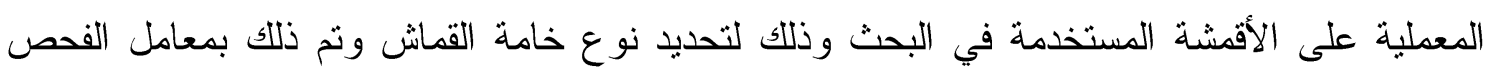

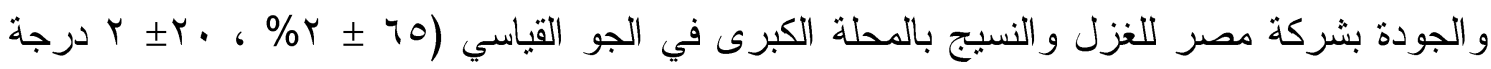

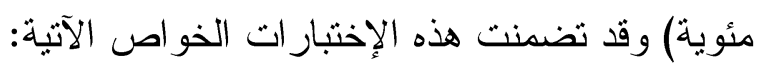

$$
\text { 1- ب إختبار الحرق: }
$$

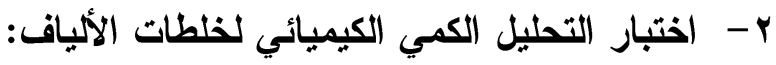

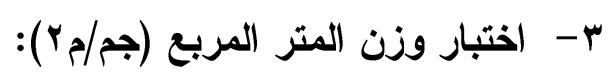

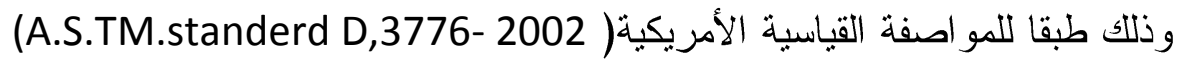

$$
\text { التجارب المعملية }
$$

وكانت إجراءات الدراسة كالآتي:

المرحلة الأولى: تجميع الوحدات الزخرفية الطبيعة:

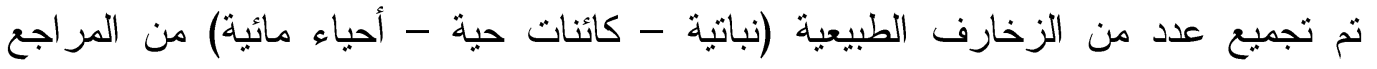

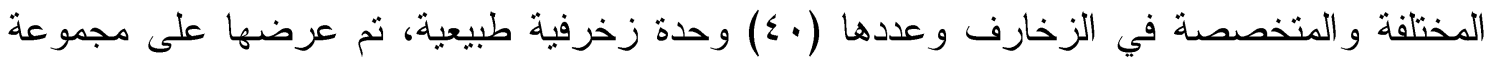

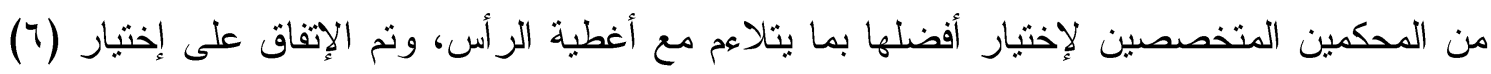

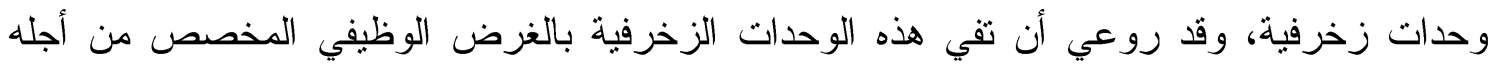

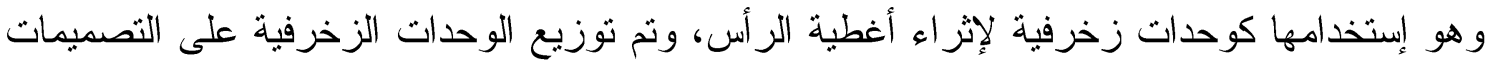

المختلفة.

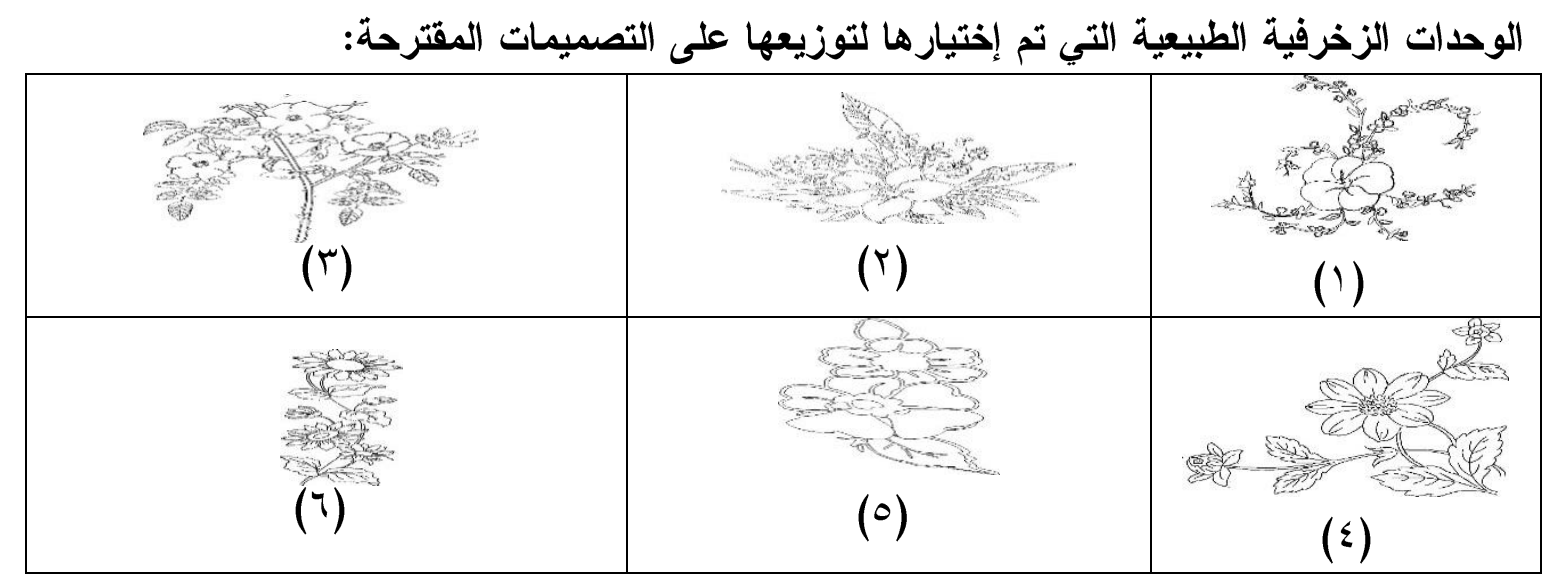

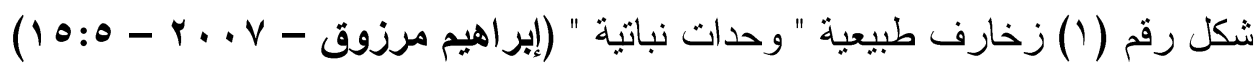


المرحلة الثانية: إعداد مجموعة من التصميمات المقترحة لأغطية الرأس (إيشاربات مسنطيلة) ووضع الوحدات الزخرفية الطبيعية عليها:

1- إعداد بعض التصميمات المقترحة لأغطية الر أس (الإيشاربات) و المتتوعة بين إيشاربات (للصباح

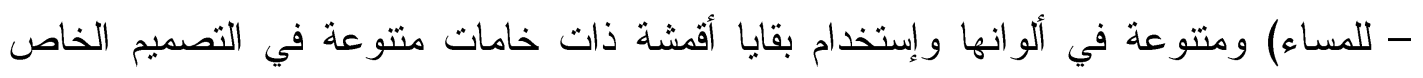
بالإيشارب (الأرضية) وكذلك في تتفيذ الزخارف المستمدة من الطبيعة لإثراء أغطية الرأس (الإيشاربات) ويتم وضع الزخارف على أغطية الر أس وذلك بإستخدام برنامج الكوريل درو. r- عدد التصميمات المقترحة (T) تصميمات.

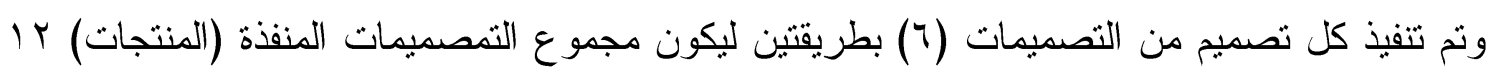
منتج ونم تقسيم هذه المنتجات (الإيشاربات) إلى ثلاث مجموعات وكل مجموعة مكونة من ع منتجات ليكون مجموع المنتجات (الإيشاربات) المنفذة (Y ( ) منتج. مجموعة (أ): تشمل (ع) منتجات تم تتفيذ الزخارف الطبيعية عليها بإستخدام أسلوب (الأبليك). مجموعة (ب): تشمل (ع) منتجات تم تنفيذ الزخارف الطبيعية عليها بإستخدام أسلوب (التطريز الآلي).

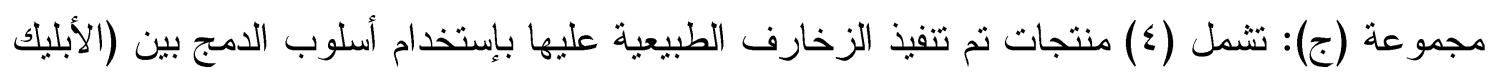
- النطريز) . ليكون عدد الإيشاربات المنفذة في النهاية (r إ) إيشارباً. تنفيذ التصميمات ببرنامج الكوريل درو:

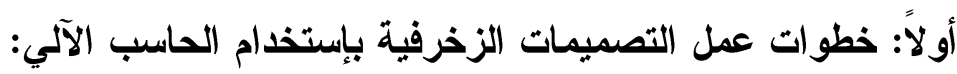
ا - يتم إدخال الزخارف الطبيعية للحاسب الآلي بإستخدام الماسح الضوئي. باسئ. r - يتم إدخال الزخارف المختارة لعمل التصميم الزخرفى إلى برنامج الكوريل درو من خلا لإنا أمر (Import (ctrl + (I)

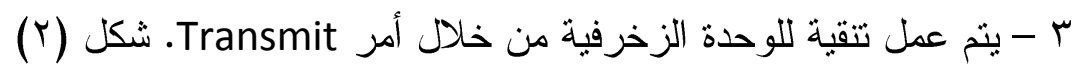
ع - يتم التعامل مع الوحدة الزخرفية و إستخدامها في عمل التصميم الزخرفى وذلك من خلال عنصر النكر ار ـ شكل (r) ثانياً: خطوات عمل تصميم الإيشارب (الأرضية) بإستخدام الحاسب الآلي:

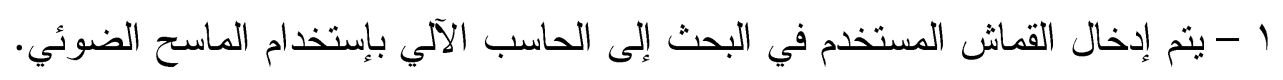

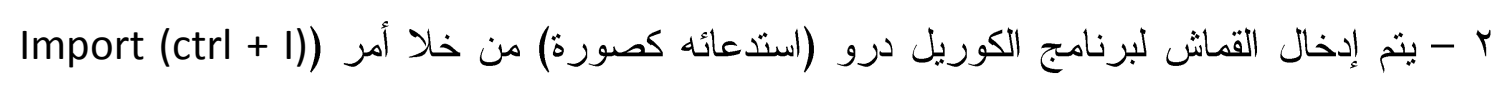

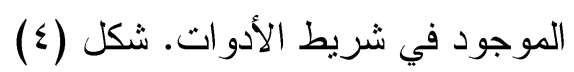
ب - يتم عمل تصميم الإيشارب (الأرضية) تبعا لذوف المصمم وبإستخدام أسس التصميم المختلفة.شكل ع - يتم دمج تصميم الإيشارب (الأرضية) مع التصميم الزخرفي بالضغط كليك يمين على التصميم و اختبار أمر (group object) لجعلهم مجموعة واحدة (تصميم و احد). شكل(T). 
(العدد الرابع) ديسمبر 17 •

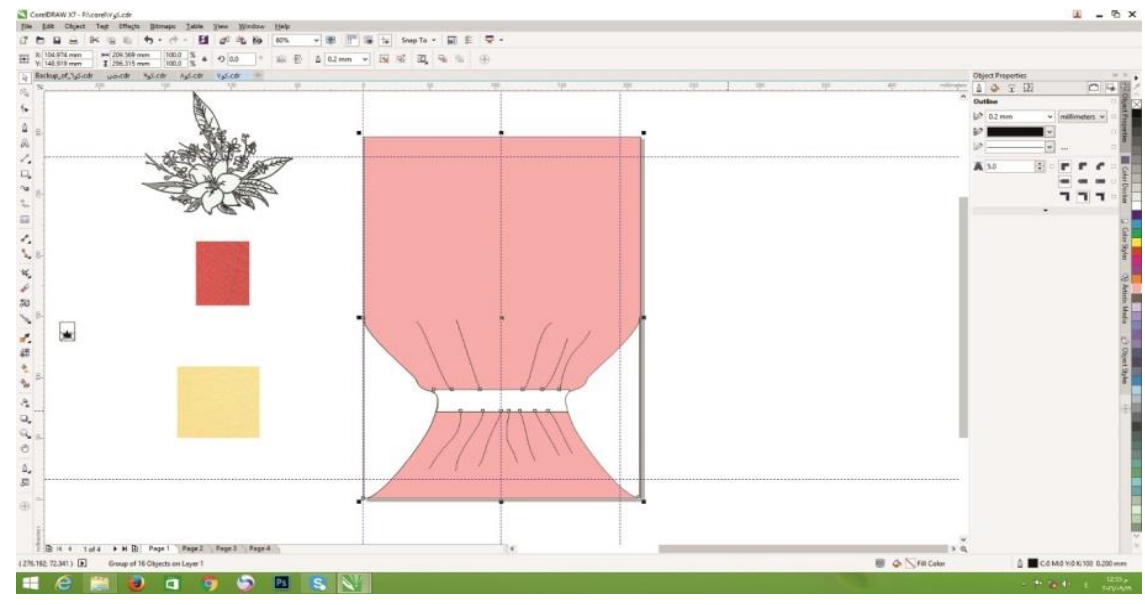

$$
\text { شكل (r) اختيار الوحدة الزخرفية }
$$

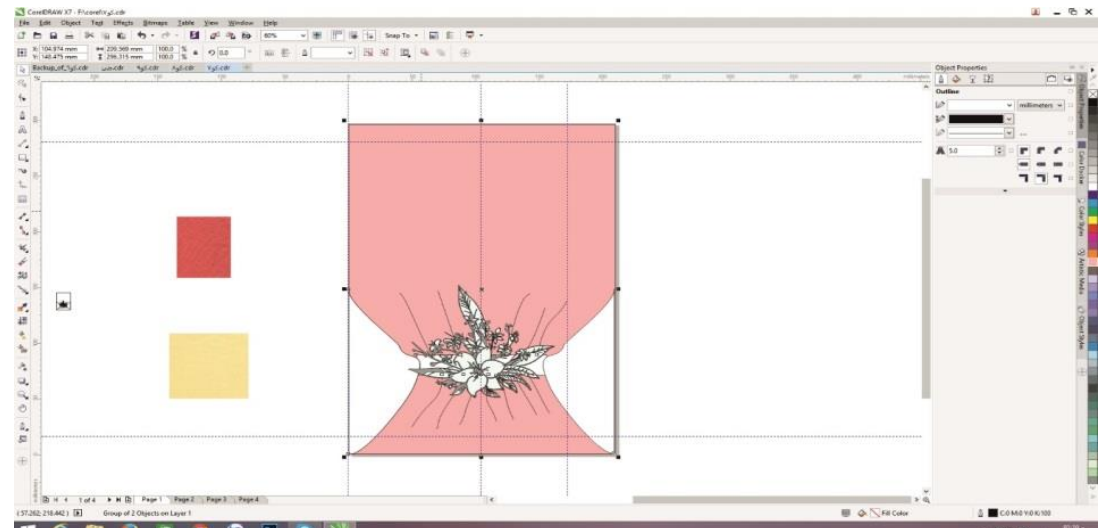

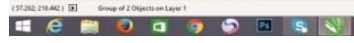

$$
\begin{aligned}
& \text { شكل (r) إستخدام الوحدة الزخرفية في عمل الثصميم الزخرفي }
\end{aligned}
$$

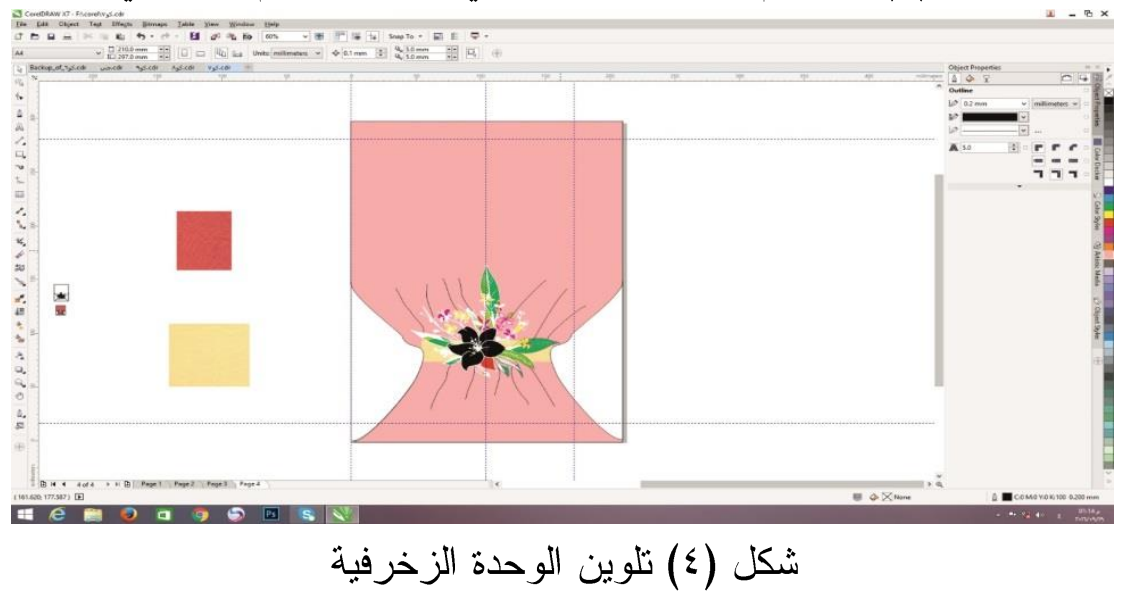




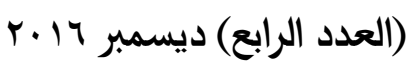

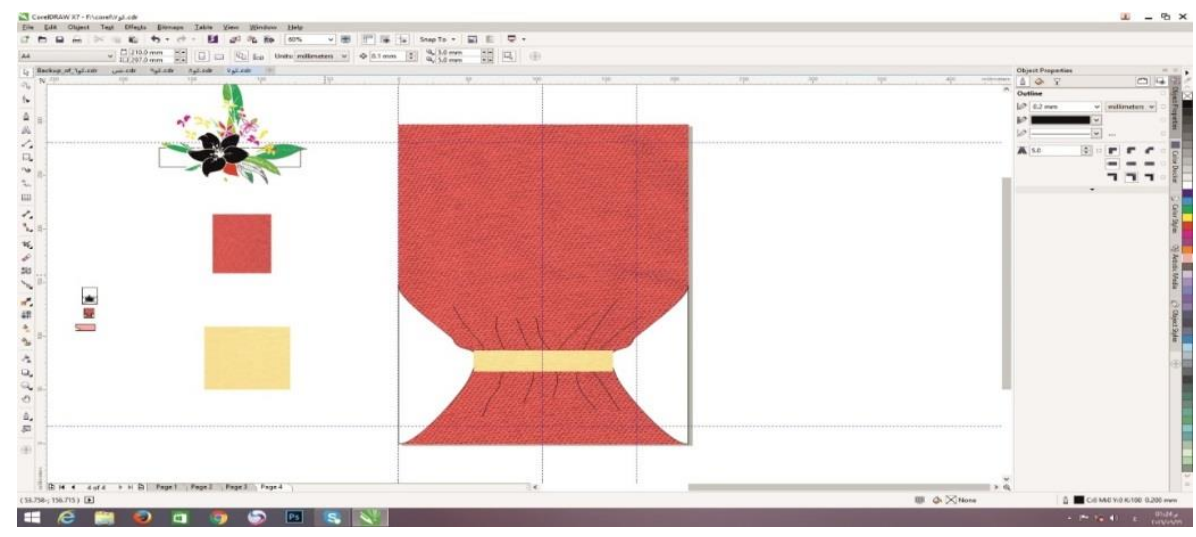

$$
\text { شكل (0) عمل تصميم الإيشارب (الأرضية) }
$$

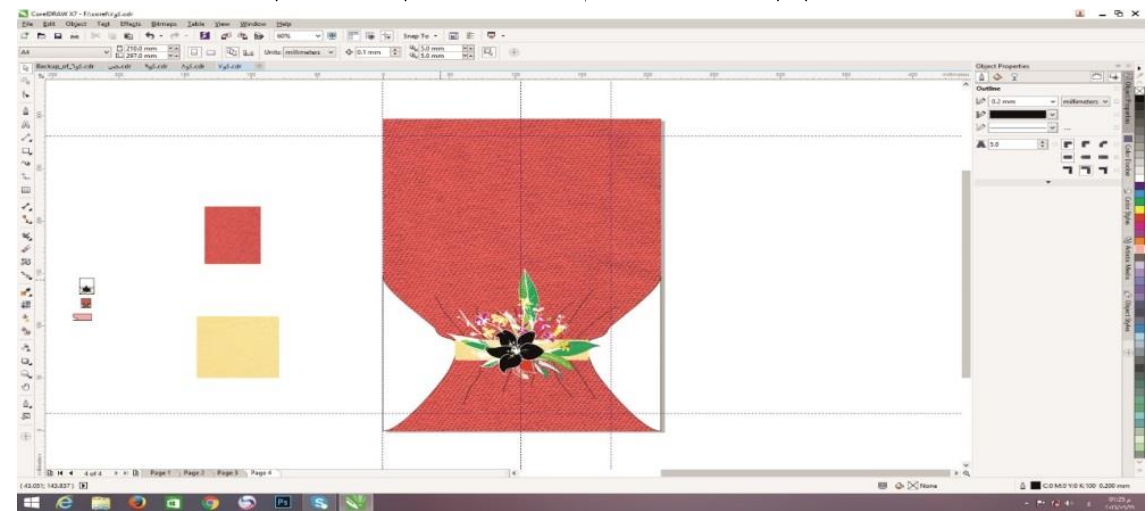

$$
\text { شكل (T) دمج تصميم الإيشارب مع التصميم الزخرفي }
$$




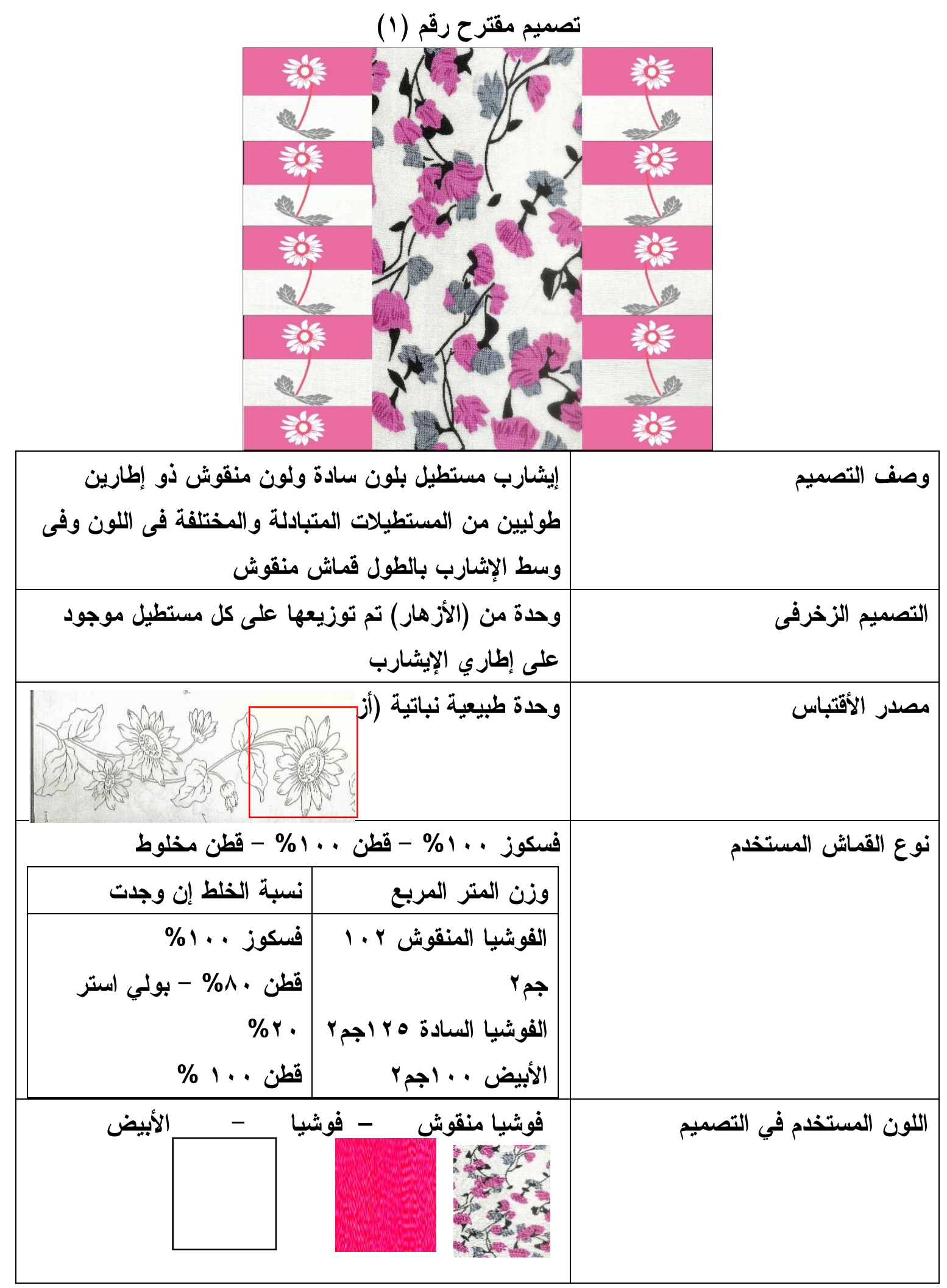




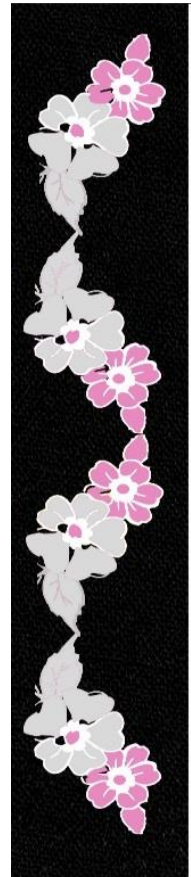

تصميم مقترح رقم (r)
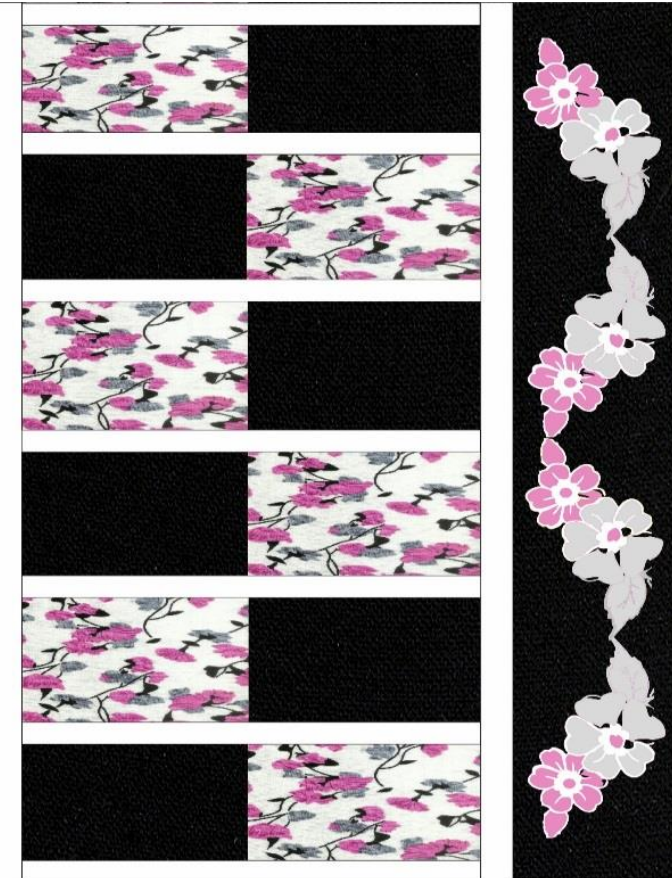

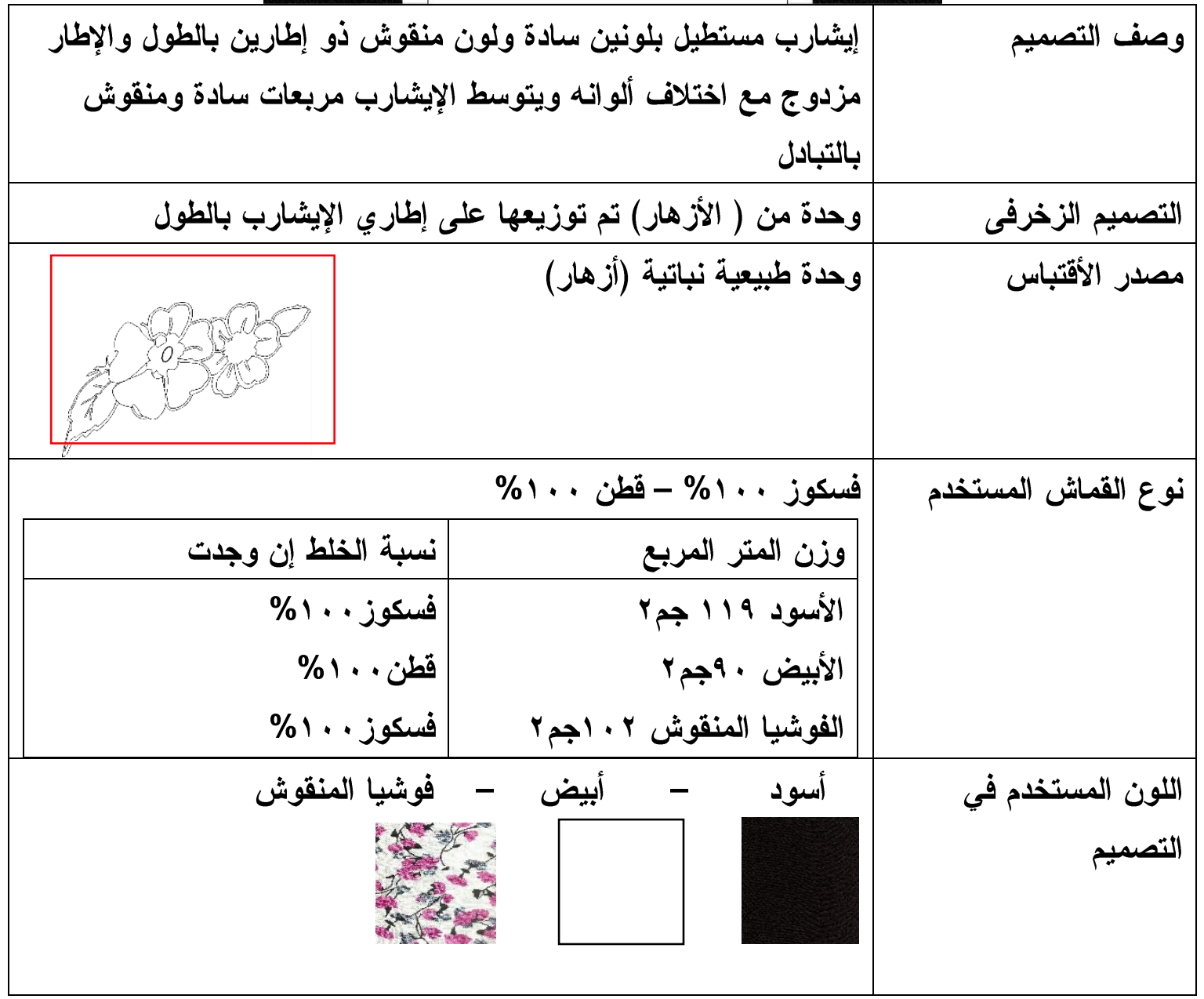


(العدد الرابع) ديسمبر 17 •

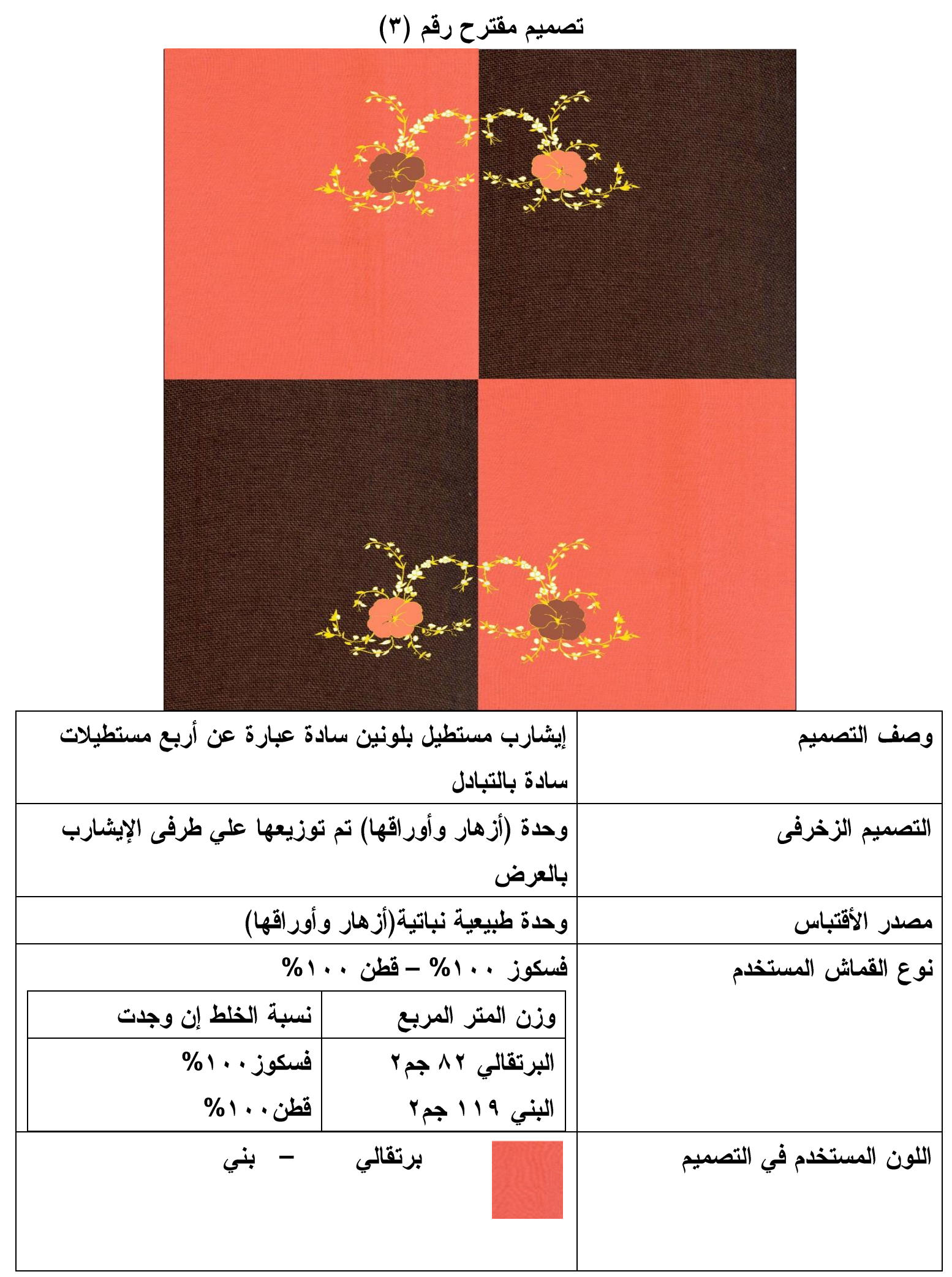




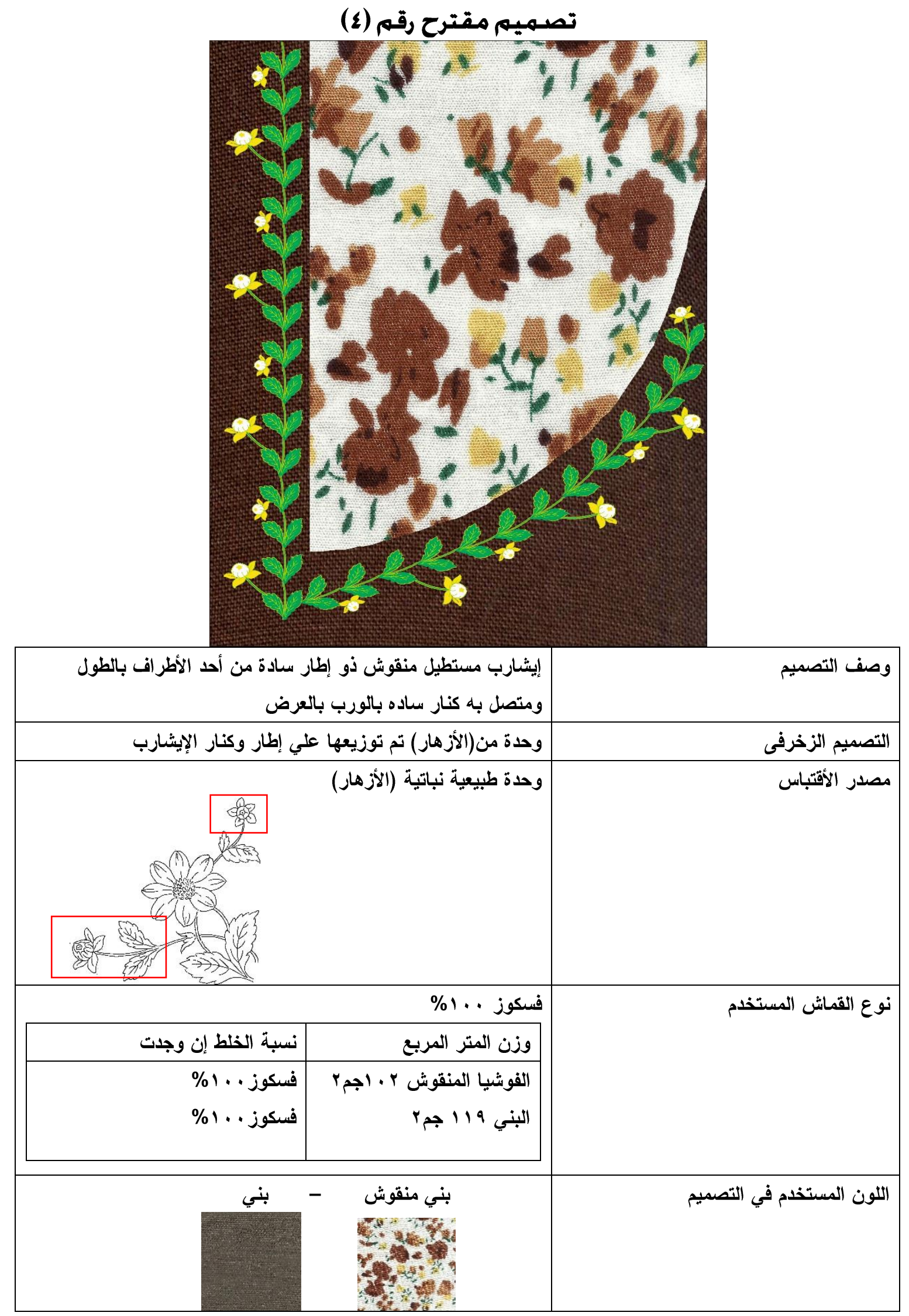


(العدد الرابع) ديسمبر 17 •

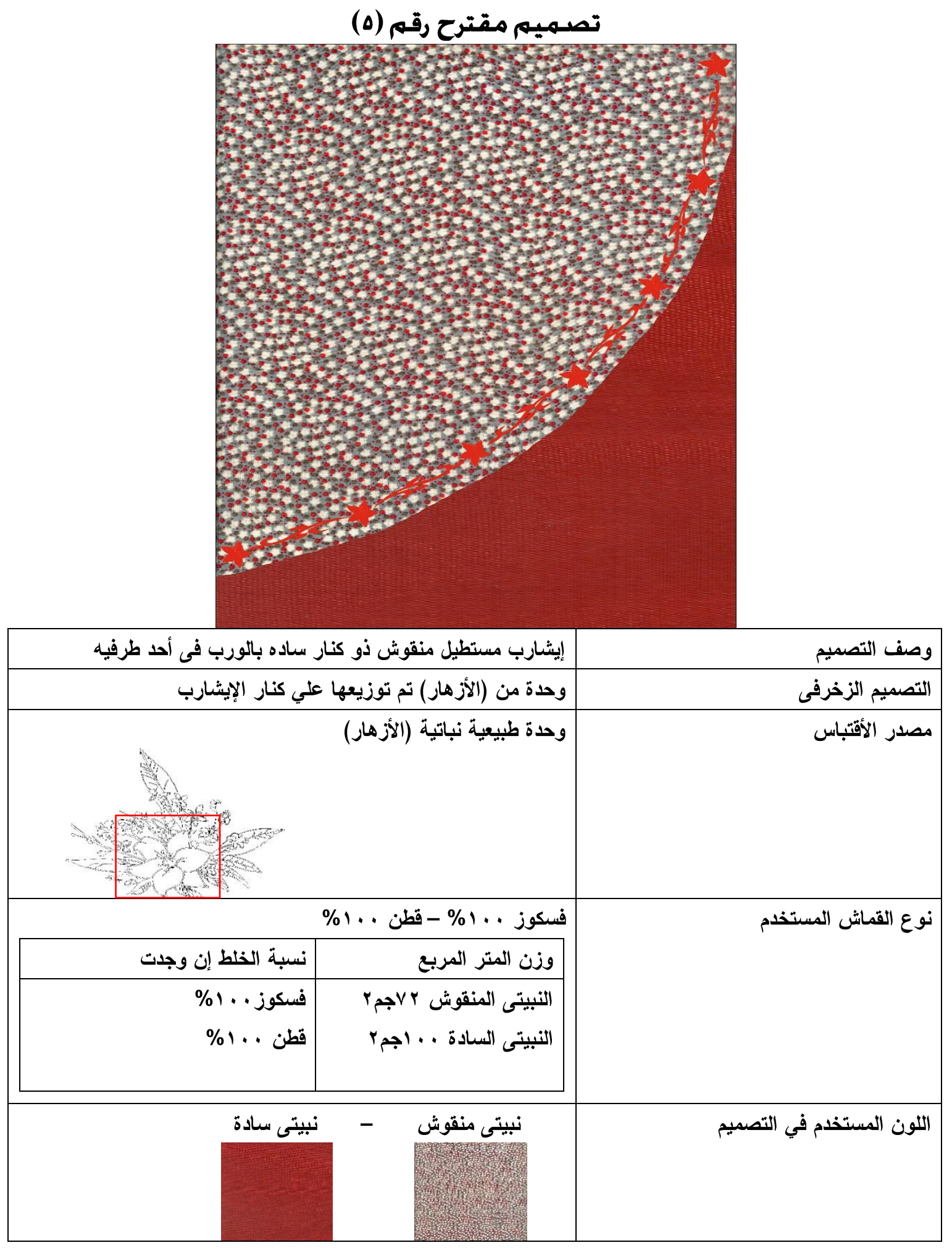


(العدد الرابع) ديسمبر 17 •

تصـيم مقترح رقم (1)

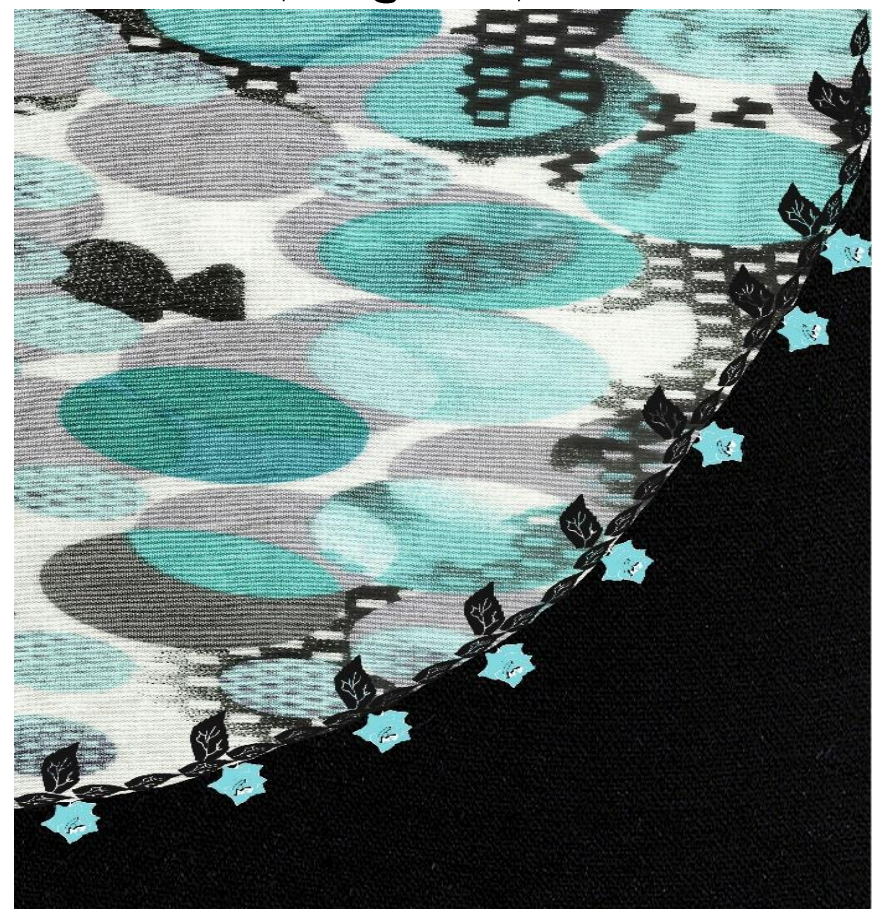

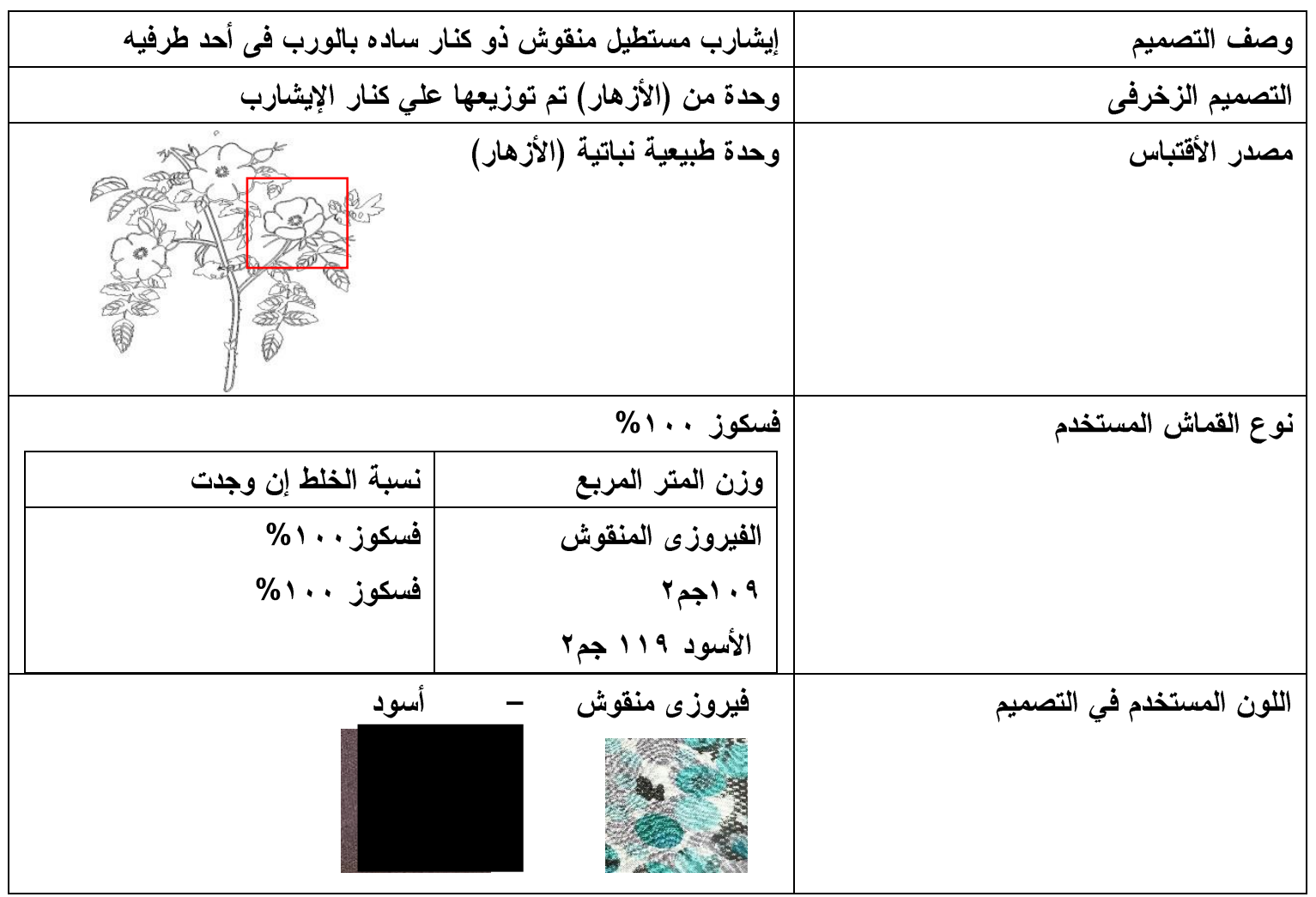


(العدد الرابع) ديسمبر 17 •

التصميمات المنفذة (المنتجات)

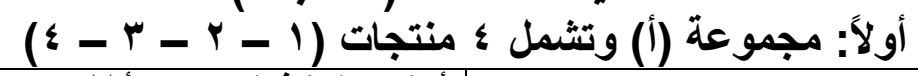

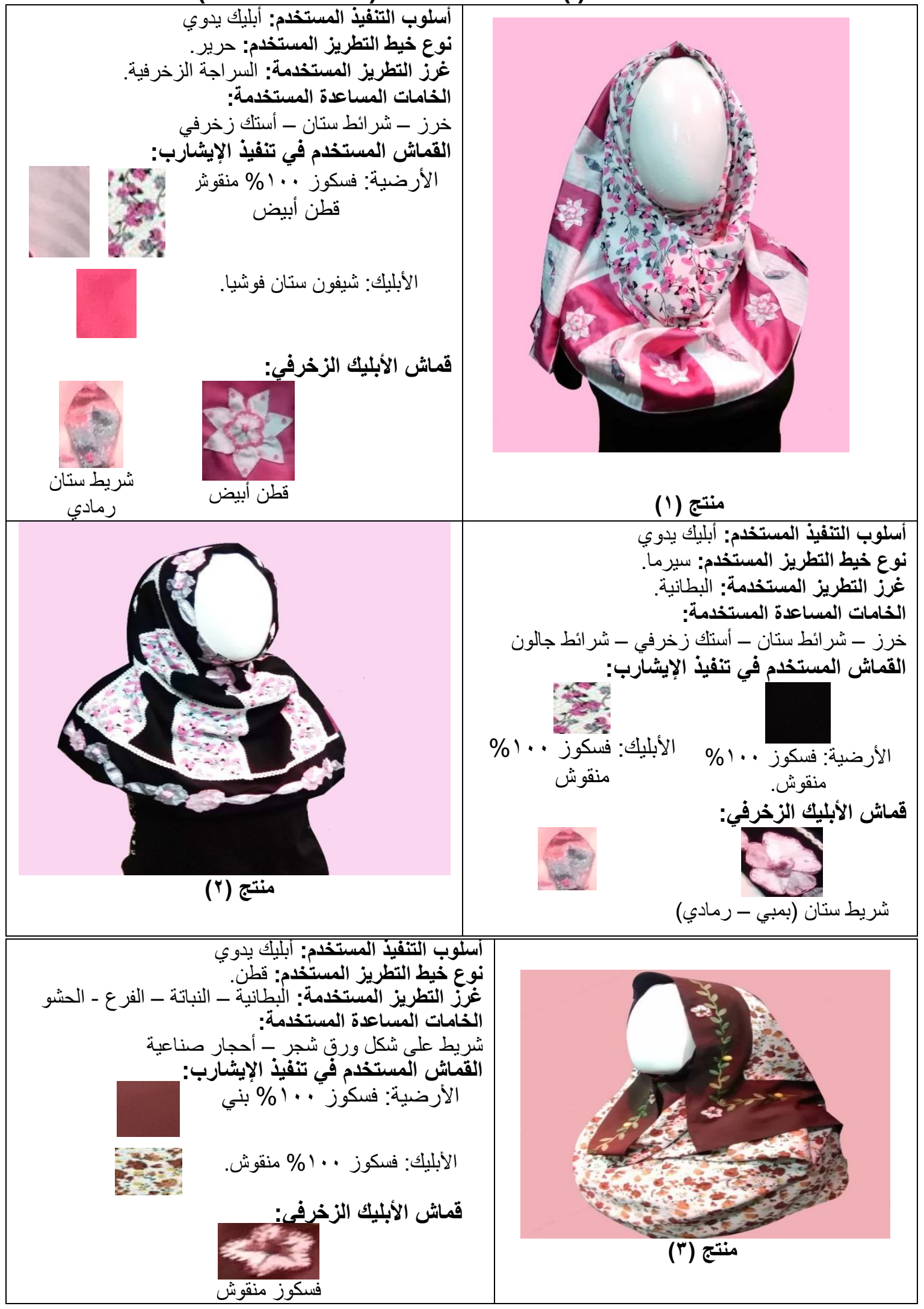




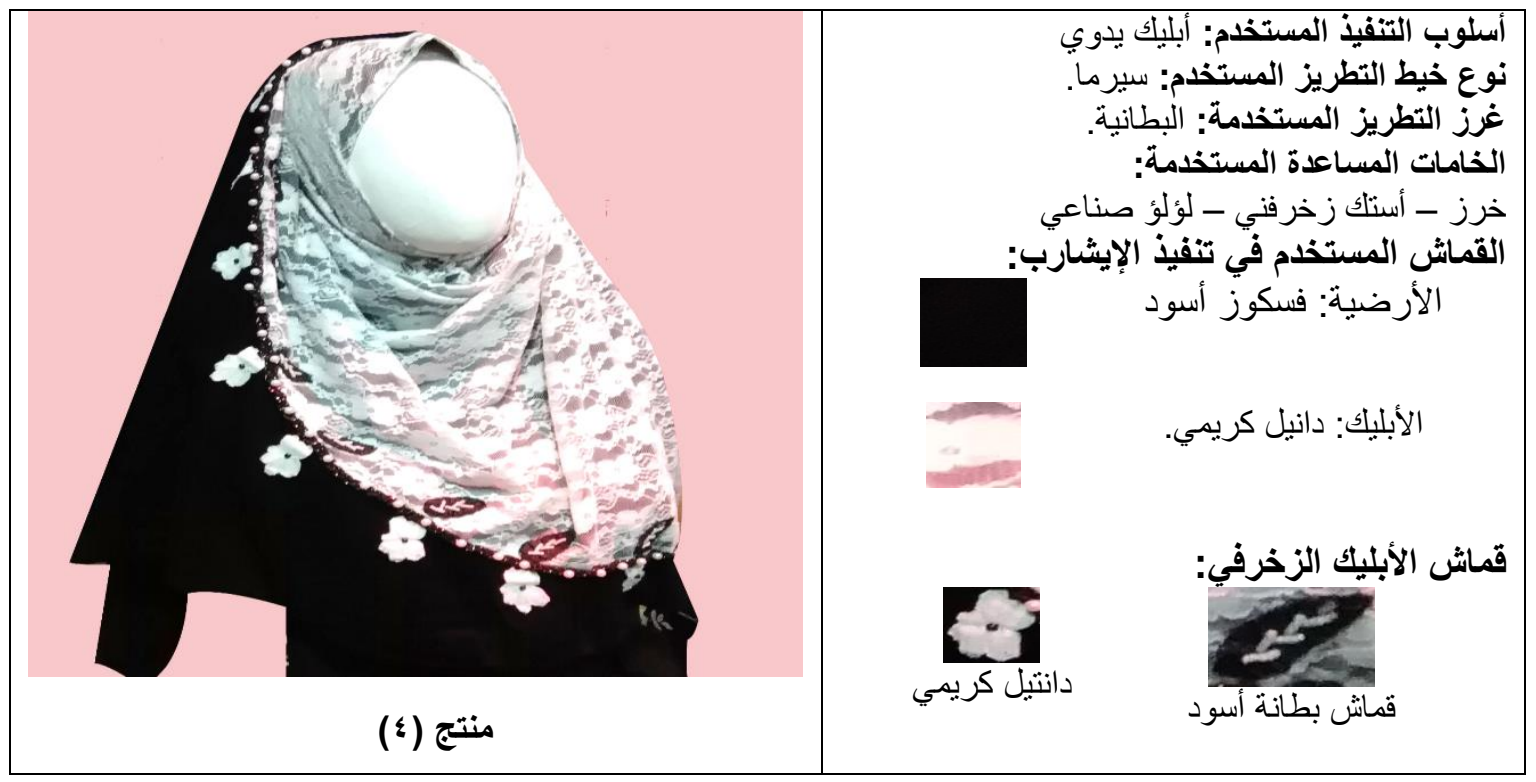

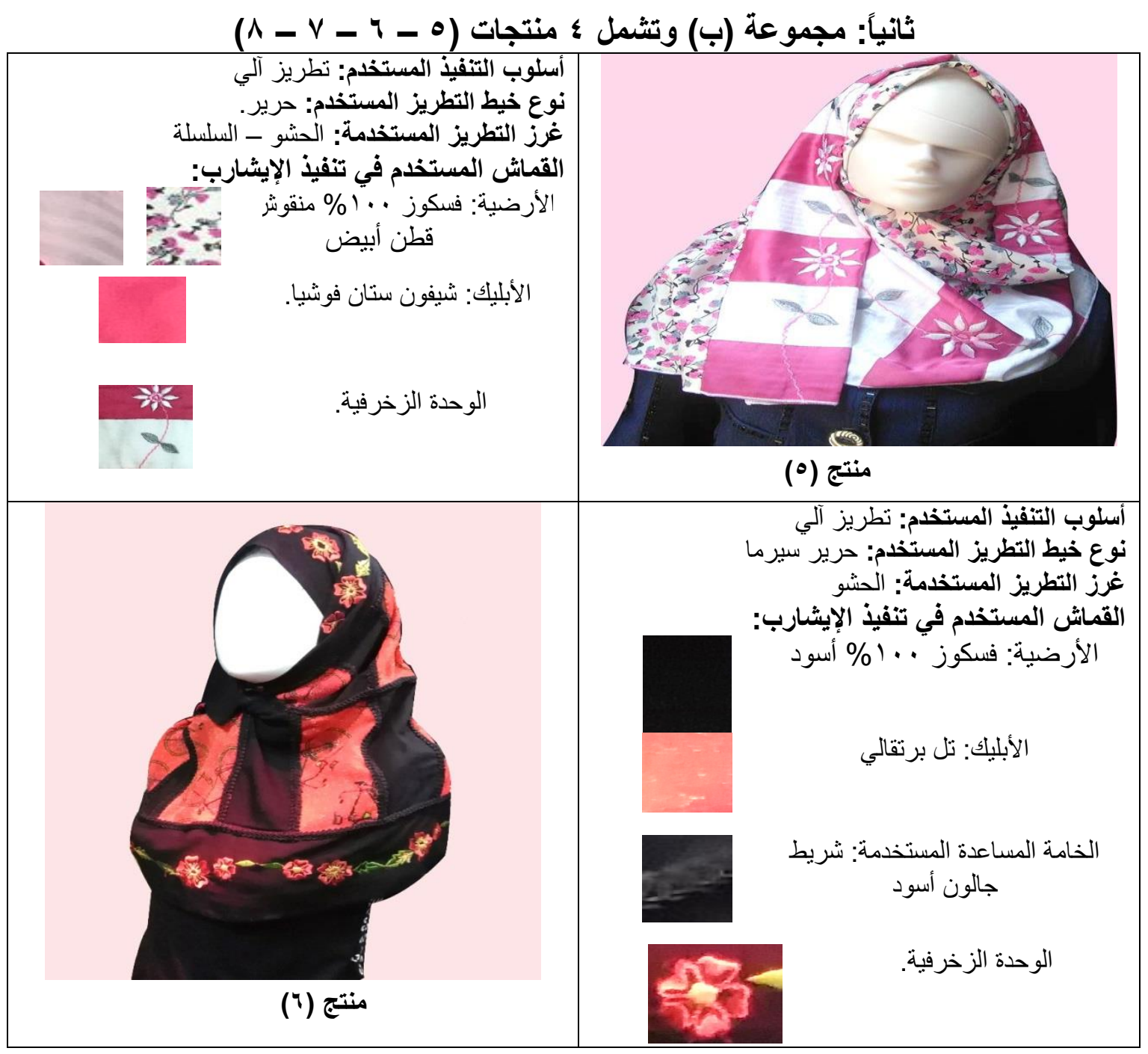




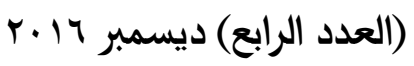

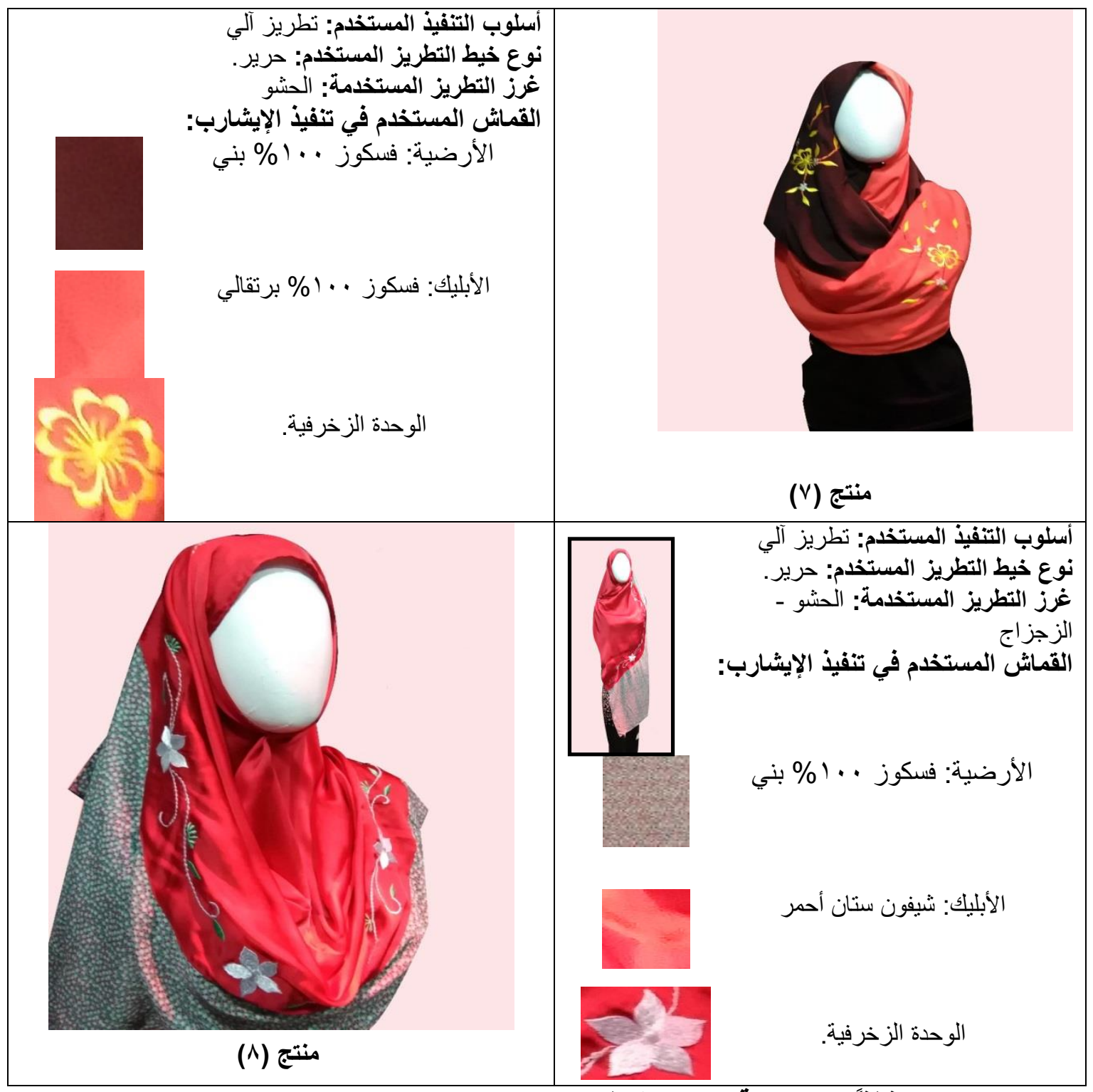

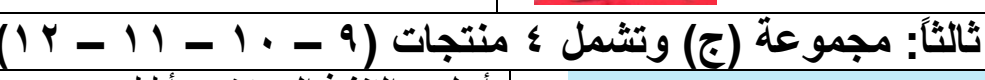

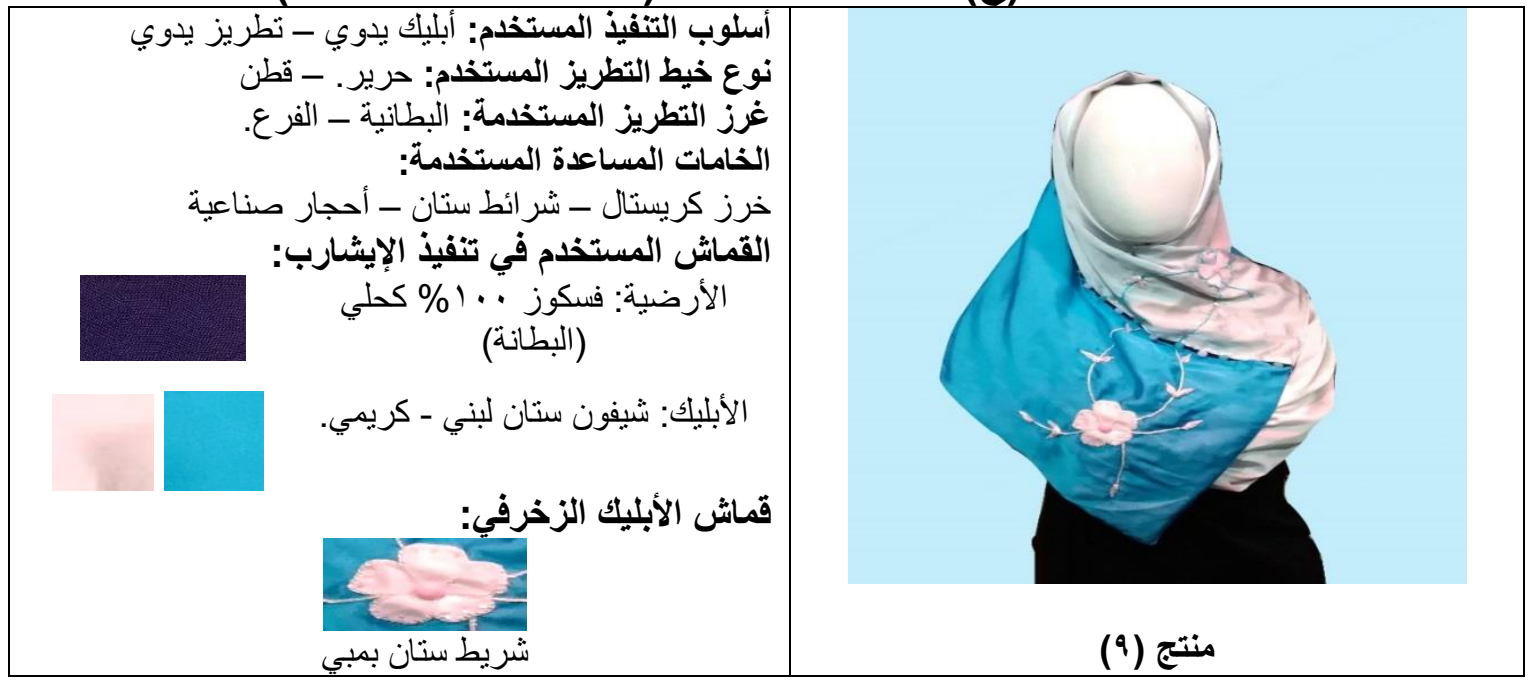


(العدد الرابع) ديسمبر 17 .

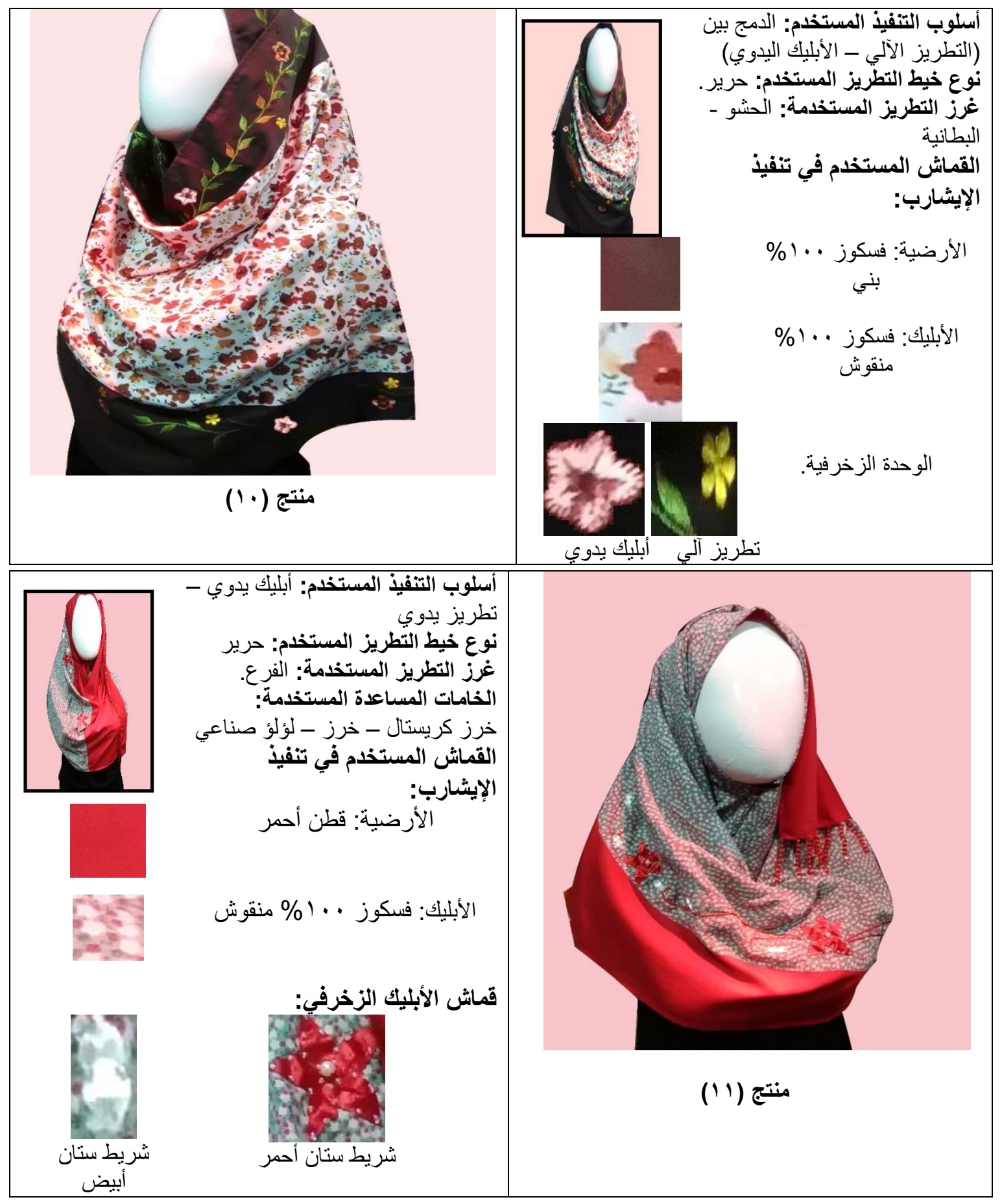




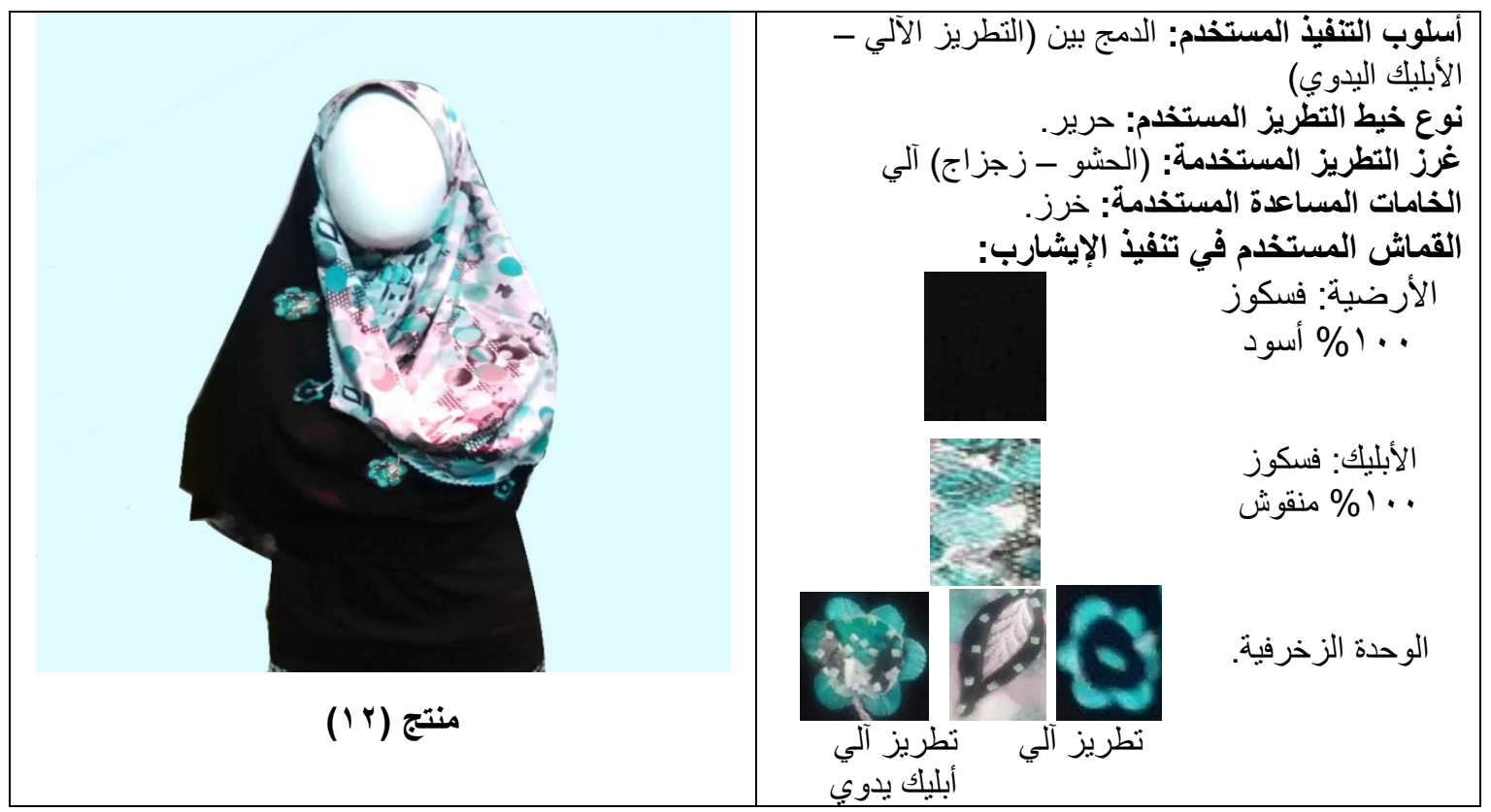

النتائج و المناقشة : الأش: الفرض الأول: توجد فروق ذات دلالة إحصائبة بين المنتجات المنفذة بالأبليك لإثراء القيم الجمالبة لأغطبة الر أس وفقا لمتوسط آراء المحكمبن: وللتحقق من هذا الفرض تم حساب تحليل التباين لمتوسط درجات المنتجات (ع منتجات) في تحقيق القيم الجمالية لأغطية الر أس وفقا لمتوسط آراء المحكمين كما هو موضح بالجدول النالي:

جدول (1): تحليل التباين لمتوسط درجات المنتجات المنفذة بالأبليك لإثراء القيم الجمالية لأغطية الرأس وفقا لمتوسط أراء المحكمين

\begin{tabular}{|c|c|c|c|c|c|}
\hline الالالة & قيمة "ف" & المربعات & الحرية & المربعات & أسلوب الأبليك \\
\hline \multirow[t]{3}{*}{. .1} & \multirow{3}{*}{ Y.ME } & $97 . \vee \wedge$ & $r$ & $r q . . r \varepsilon$ & بين المجموعات \\
\hline & & $\{1 . \varepsilon Y$ & $r \wedge$ & 1109.74 & داخل المجموعات \\
\hline & & & $m$ & $1 \leq \varepsilon 9.9 V$ & المجموع \\
\hline
\end{tabular}

تشير نتائج الجدول السابق إلى أن قيمة (ف) كانت (ع r.r) وهي قيمة غير دالة إحصائياً عند مستوي (1 +..) مما يدل على عدم وجود فروق بين المنتجات المنفذة بالأبليك لإثراء القيم الجمالية لأغطية الر أس وفقا لآر اء المحكمين، والجدول التالي يوضح المتوسطات والإنحر افات المعيارية لتقييم المحكمين للمنتجات. 
جدول (Y): المتوسطات والإنحر افات المعيارية لتقييم المحكمين للمنتجات المنفذة بالأبليك لإثراء القيم

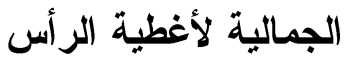

\begin{tabular}{|c|c|c|c|}
\hline ترتيب المنتجات & الاتحر اف المعياري & المتوسط & التصميم \\
\hline$\varepsilon$ & $V . \varepsilon q$ & rr.IT & (7) \\
\hline r & 7.9. & $r 0.1 \mu$ & (9) \\
\hline r & V.VI & $r \varepsilon .0$. & $\left(\mu_{0}\right)$ \\
\hline 1 & 1.7. & $\varepsilon . . r \Lambda$ & $(r v)$ \\
\hline
\end{tabular}

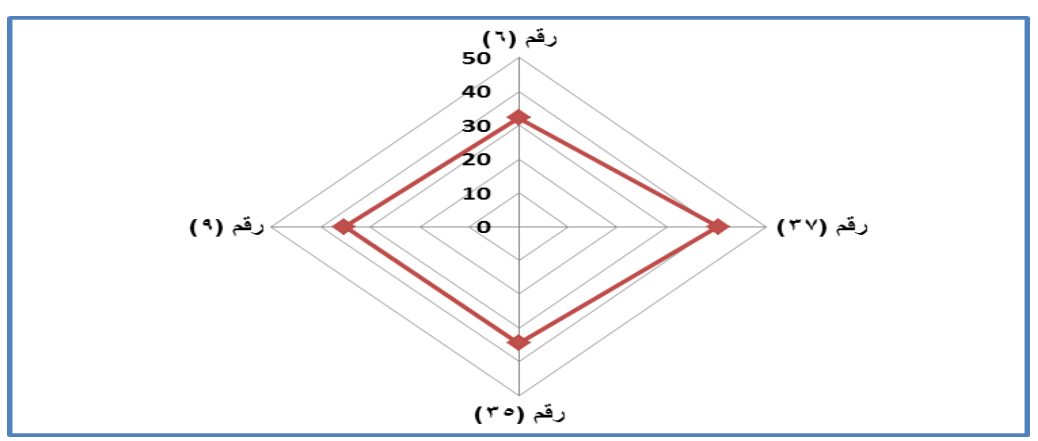

شكل (V): متوسطات تقيمات المنتجات المنفذة بالأبليك لإثراء القيم الجمالية لأغطية الرأس وفقا

$$
\text { لمتوسط أراء المحكمين. }
$$

من الجدول (Y) و الثكل (V) يتضح عدم وجود فروق دالة إحصائباً بين المنتجات عند مستوي 1... فنجد أن المنتج السابع والثلاثون كان أفضل المنتجات يليه المنتج التاسع، يليه المنتج الخامس و الثثلاثون، يليه السادس.

الفرض الثاني: توجد فوق ذات دلالة إحصائبة بين المنتجات المنفذة بالتطريز لإثراء القيب الجمالبة لأغطية الر أس وفقاً لمتوسط آراء المحكمين: وللتحقق من هذا الفرض نم حساب تحليل التباين لمتوسط درجات المنتجات (ع منتجات) في تحقيق القيم الجمالية لأغطية الر أس وفقا لمتوسط آر اء المحكمين وجدول (ب) يوضح ذلكابن جدول (r): تحليل التباين لمتوسط درجات المنتجات المنفذة بالتطريز لإثراء القيم الجمالية لأغطية الر أس وفقاً لمتوسط آراء المحكمين

\begin{tabular}{|c|c|c|c|c|c|}
\hline الدلالة & قيمة "ف" & المربعات & الحرجية & المربعات مجوع & أسلوب التطريز \\
\hline \multirow{3}{*}{$\cdots$} & \multirow{3}{*}{ IA.Ar } & $\varepsilon \cdot r . \varepsilon r$ & $r$ & $|r| \ldots r o$ & بين المجموعات \\
\hline & & rI.\&Y & $r \wedge$ & ०१৭.V० & داخل المجموعات \\
\hline & & & r & $|\wedge| \ldots$ & المجموع \\
\hline
\end{tabular}




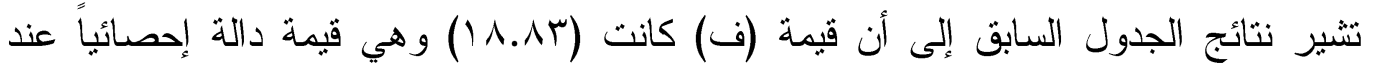
مستوي (1 (..) مما بدل على وجود فروق بين المنتجات المنفذة بالنطريز لإثراء القيم الجمالية لأغطية الر أس وفقا لمتوسط آر اء المحكمين، و الجدول التالي يوضح المتوسطات و الإنحر افات المعيارية لتقبيم المحكمين للمنتجات.

جدول (ء): المتوسطات والإنحر افات المعيارية لتقييم المحكين للتصميمات المنفذة بالتطريز لإثراء القيم الجمالية لأغطية الرأس

\begin{tabular}{|c|c|c|c|}
\hline ترتيب التصميمات & الاتحراف المعياري & المتوسط & التصميم \\
\hline$\varepsilon$ & $V . V r$ & rq.ro & $(7)$ \\
\hline r & $\varepsilon . \wedge \varepsilon$ & rv.ru & (9) \\
\hline 1 & 1.17 & $\varepsilon \varepsilon . r_{0}$ & $(r \cdot)$ \\
\hline r & $1.1 \%$ & $\varepsilon \varepsilon .1 \%$ & $(r q)$ \\
\hline
\end{tabular}

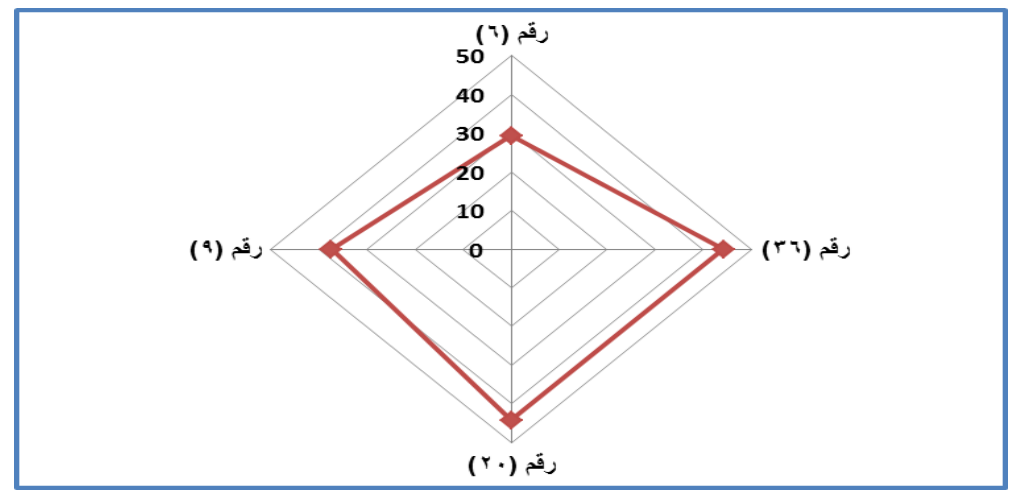

شكل (^): متوسطات تقييمات المنتجات المنفذة بالتطريز لإثراء القيم الجمالية لأغطية الرأس وفقاً لمتوسط آراء المحكمين.

من الجدول (ع) و الشكل (^) يتضح وجود فروق دالة إحصائياً بين المنتجات عند مستوي ا ـ... فنجد أن المنتج العشرون كان أفضل المنتجات يليه المنتج الساد و الثلاثون، يليه المنتج الثاسع، يليه السادس. الفرض الثالث: توجد فروق ذات دلامة إحصائبة بين المنتجات المنفة بالدمج (التطريز - الأبليك) لإثر اء القيم الجمالبة لأغطبة الر أس وفقاً لمتوسط آراء المحكين: وللتحقق من هذا الفرض تم حساب تحليل التباين لمتوسط درجات المنتجات (ع منتجات) في

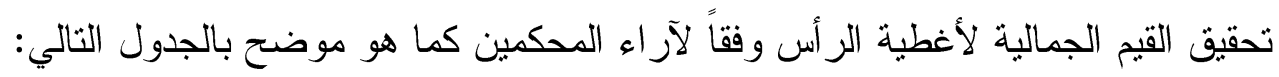




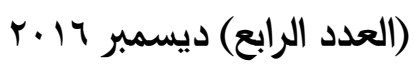

جدول (•): تحليل التباين لمتوسط درجات المنتجات المنفذة بالامج (التطريز - الأبليك) لإثراء القيم الجمالية لأغطية الر أس وفقاً لمتوسط آراء المحكمين

\begin{tabular}{|c|c|c|c|c|c|}
\hline الدلالة & قيمة "ف" & المربعات & الحرية & المربعات & الامج (التطريز - الأبليك) \\
\hline \multirow{3}{*}{$\cdot . r$} & r.07 & 9.01 & $r$ & rA.Vo & بين المجموعات \\
\hline & & 9.79 & rr & AT.YY & داخل المجموعات \\
\hline & & & هo & $11 \leq .9 V$ & المجموع \\
\hline
\end{tabular}

تشير نتائج الجدول السابق إلى أن قيمة (ف) كانت (با.07) وهي قيمة دالة إحصائياً عند

مستوي (1 +.•) مما يدل على وجود فروق بين المنتجات المنفذة بالدمج (النطريز - الأبليك) لإثراء القيم الجمالية لأغطية الر أس وفقاً للآراء المحكمين، و الجدول التالي يوضح المتوسطات والإنحرافات المعيارية لتقييم المحكمين للمنتجات. جدول (†): المتوسطات والإنحر افات المعيارية لتقييم المحكين للمنتجات المنفذة بالامج (التطريز الأبليك) لإثر اء القيم الجمالية لأغطية الرأس السهاب

\begin{tabular}{|c|c|c|c|}
\hline ترتيب المنتجات & الانحر اف المعياري & المتوسط & المنتج \\
\hline r & $1 . v r$ & $\varepsilon r \ldots$ & $(r \cdot)$ \\
\hline$\varepsilon$ & $1 . \wedge V$ & $\varepsilon Y .7 V$ & $(\mu \Delta)$ \\
\hline 1 & $\cdots$ & $\varepsilon 0 \ldots$ & $(r q)$ \\
\hline r & $r . . V$ & $\varepsilon r . \varepsilon \varepsilon$ & $(r v)$ \\
\hline
\end{tabular}

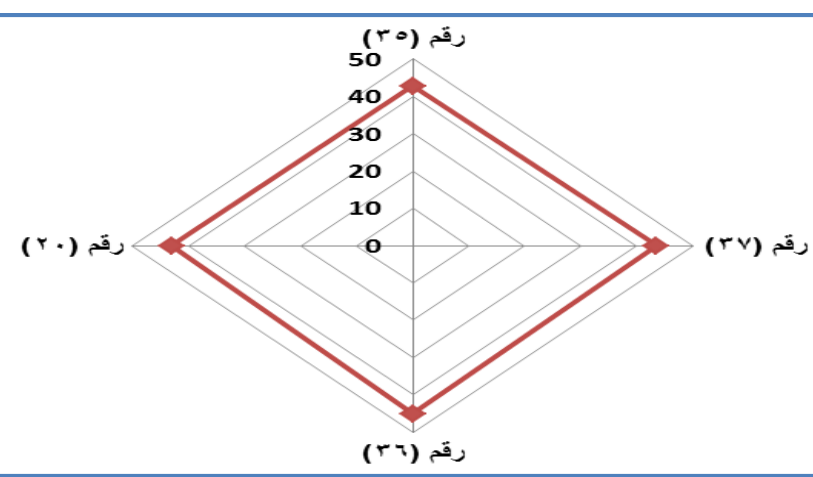

شكل (9): متوسطات تقييمات المنتجات المنفذة بالامج (التطريز - الأبليك) لإثراء القيم الجمالية لأغطية الر أس وفقاً لمتوسط آراء المحكمين.

من الجدول (7) و الثكل (9) يتضح وجود فروق دالة إحصائياً بين المنتجات عند مستوي ا... فنجد أن التصميم الساد و الثلاثون كان أفضل المنتجات يليه المنتج السابع و الثلاثون، يليه المنتج الخمسة و الثناثون، يليه العشرون. 


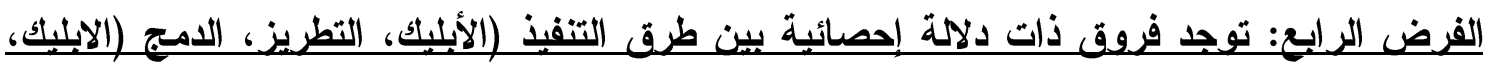
التطريز) للمنتجات المنفذة وفقا لمتوسط آراء المحكمين: وللتحقق من هذا الفرض تم حساب تحليل التباين لمتوسط طرق التنفئنيذ (الأبليك، النطريز،

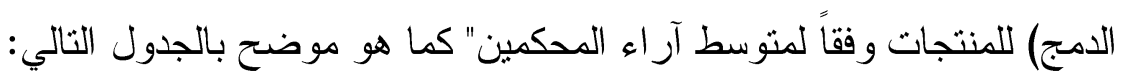

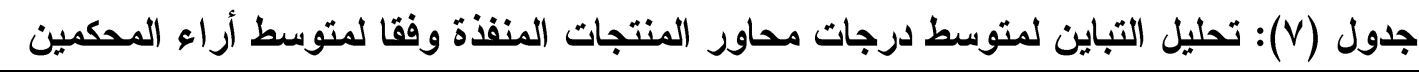

\begin{tabular}{|c|c|c|c|c|c|}
\hline الدلالة & قيمة "ف" & الحرية & متوسط المربعات & مجموع المربعات & طرق التنفيذ \\
\hline \multirow{3}{*}{$\cdots$} & \multirow{3}{*}{10.19} & Dor.Ao & $r$ & $11.0 . v$. & بين المجموعات \\
\hline & & $r \varepsilon . \vee q$ & qV & $r T V \varepsilon . q \varepsilon$ & داخل المجموعات \\
\hline & & & 99 & $\leqslant \varepsilon \wedge \cdot . \neg \leqslant$ & المجموع \\
\hline
\end{tabular}

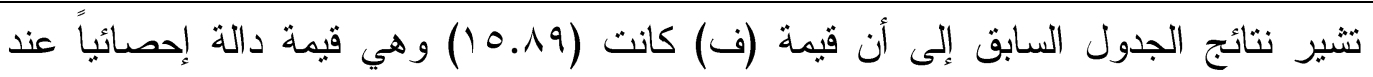

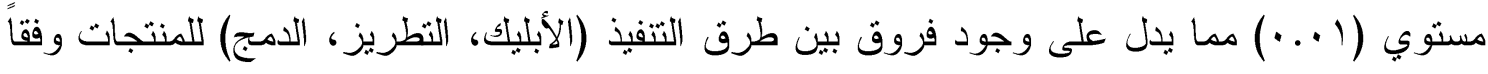

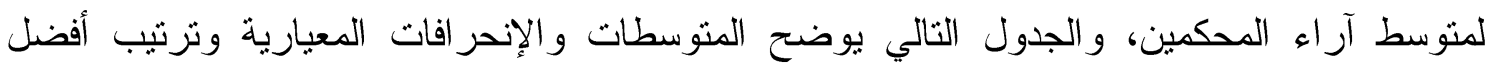
الطرق في ضو هو تقييمات المحكمين. جدول (^): المتوسطات والإنحر فاتات المعيارية لطرق التتفيذ (الأبليك، التطريز، الامج) للمنتجات وفقاً لمتوسط آراء المحكمين

\begin{tabular}{|c|c|c|c|}
\hline ترتيب المحاور & الالحعراف & المتوسط & 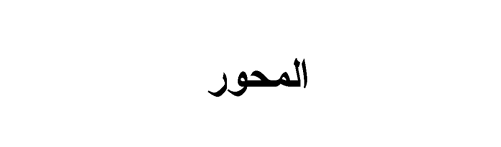 \\
\hline$r$ & $\Upsilon . \wedge \varepsilon$ & ro.or & أسلوب (الأبليك) \\
\hline r & $V .7 \varepsilon$ & ru.vo & أسلوب (التطريز) \\
\hline 1 & 1.11 & $\varepsilon r . \Delta r$ & أسلوب الامجج (التطريز - الأبليك) \\
\hline
\end{tabular}




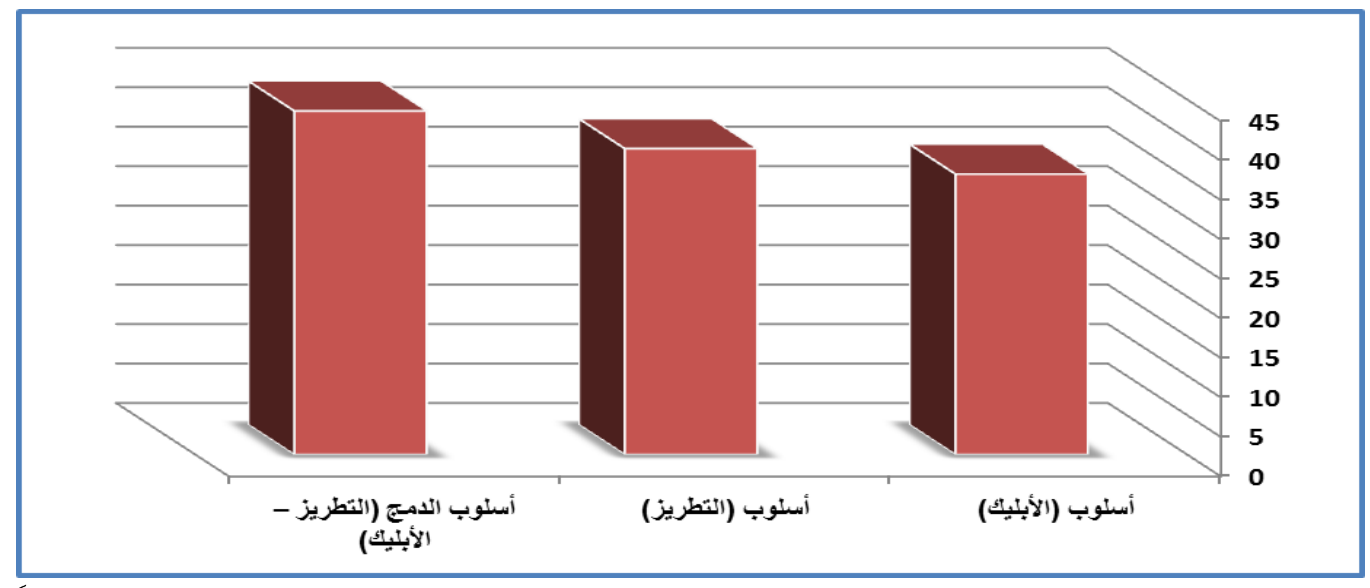

شكل (· 1): متوسطات تقيمات طرق التنفيذ (الأبليك، التطريز، الامج) للمنتجات وفقاً لمتوسط آراء المحكمين.

من الجدول (^) و الشكل (• () فنجد أن أسلوب الدمج (التطريز - الأبليك) أفضل طرق للتنفيذ يليه أسلوب النطريز ، يليه أسلوب الأبليك.

الفرض الخامس: توجد فروق ذات دلالة إحصائبة بين المنتجات المنفذة بالطرق (الأبليك، التطريز، الامجج (الابليك، التطريز) وفقاً لمتوسط آراء المحكمين: وللتحقق من هذا الفرض ثم حساب تحليل التباين بين المنتجات المنفذة بالطرق (الأبليك، التطريز، الامج (الابليك، التطريز) وفقاً لمتوسط آر اء المحكمين" كما هو موضتح بالجدول التالي: جدول (9): تحليل التباين للمنتجات المنفذة بالطرق (الأبليك، التطريز، الدمج (الابليك، التطريز)

\begin{tabular}{|c|c|c|c|c|c|}
\hline الالالة & قيمة "ف" & الحرية & المربعات & المربعات مجوع & المنتجات \\
\hline \multirow{3}{*}{$\cdots$} & \multirow{3}{*}{$11 . \varepsilon Y$} & rrq.00 & 11 & צ... & بين المجموعات \\
\hline & & $r . .9 V$ & $\wedge \wedge$ & $1 \wedge \leq 0.7$. & داخل المجموعات \\
\hline & & & 99 & $\varepsilon \leqslant \Lambda \cdot .7 \varepsilon$ & المجموع \\
\hline
\end{tabular}

تشير نتائج الجدول السابق إلى أن قيمة (ف) كانت (بع. (I)) وهي قيمة دالة إحصائياً عند مستوي (1 +..) مما يدل على وجود فروق بين المنتجات المنفذة بالطرق (الأبليك، التطريز، الدمج (الابليك، النطريز)، و الجدول النالي يوضح المتوسطات و الإنحر افات المعيارية ونزتيب أفضل المنتجات في ضوء تقيمات المحكمين. 
r (العدد الرابع) ديسمبر 17

جلول ( • 1): المتوسطات والإنحر افات المعيارية لطرق التنفيذ (الأبليك، التطريز، الامج) للمنتجات وفقاً لمتوسط آراء المحكمين

\begin{tabular}{|c|c|c|c|c|}
\hline الترتيب ككل & ترتيب في ضوء الطريقة & المتوسط & المنتج & طريقة التنفيذ \\
\hline 11 & $\varepsilon$ & rr.Ir & 7 & \multirow{4}{*}{ الأبليك } \\
\hline 9 & r & r r & 9 & \\
\hline 1. & $r$ & $r \varepsilon .0$. & ro & \\
\hline V & 1 & ^ & $r v$ & \\
\hline Ir & $\varepsilon$ & rq.Yo & 7 & \multirow{4}{*}{ التطريز } \\
\hline$\Lambda$ & $r$ & rV.rA & 9 & \\
\hline$r$ & 1 & $\varepsilon \varepsilon . Y_{0}$ & $r$. & \\
\hline$r$ & $r$ & & r & \\
\hline 0 & $r$ & $\varepsilon r . \ldots$ & $r$. & \multirow{4}{*}{ الامجج (التطريز - الأبليك) } \\
\hline 7 & $\varepsilon$ & $\varepsilon r . T V$ & ro & \\
\hline 1 & 1 & $\varepsilon 0 \ldots$ & דr & \\
\hline$\varepsilon$ & $r$ & $\varepsilon r . \varepsilon \varepsilon$ & $r v$ & \\
\hline
\end{tabular}

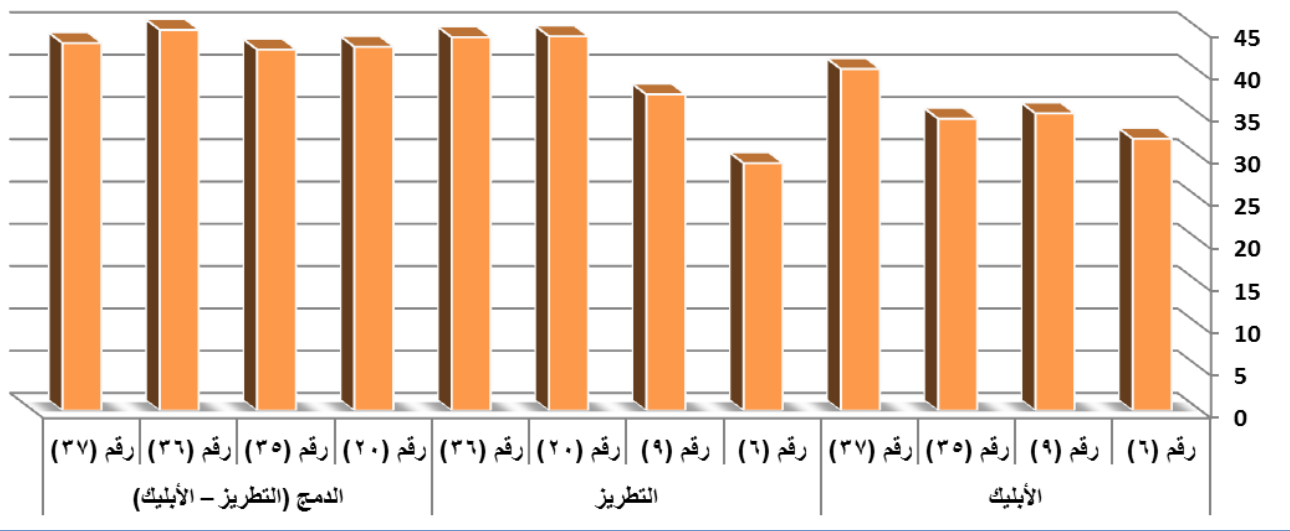

شكل (1 (1): متوسطات تقييمات طرق التنفيذ (الأبليك، التطريز، الامج) للمنتجات وفقاً لمتوسط آراء المحكمين.

$$
\text { من الجدول (• ()) و الثكل (1) فنجد أن: }
$$

1- جاءت أفضل المنتجات على الإطلاق المنتج (بץ) و المنفذ بأسلوب الدمج (النطريز

و الأبليك)، بينما جاءت أقل المنتجات هو المنتج (T) و المنفذ بأسلوب التطريز. 


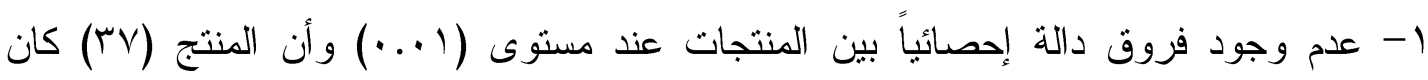

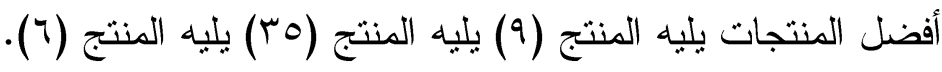

r- وجود فروق بين المنتجات المنفذة بالتطريز لإثراء القيم الجمالية لأغطية الرأس (الإيشاربات)

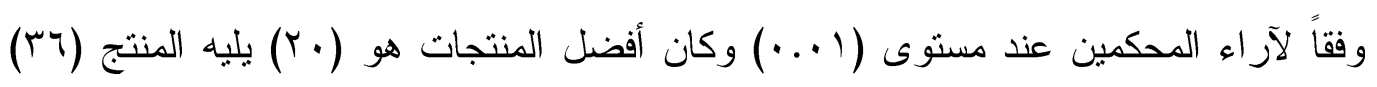

يليه المنتج (9) يليه المنتج (T).

r- وجود فروق بين المنتجات المنفذة بالدمج (النطريز/ الأبليك) لإثراء القيم الجمالية لأغطية

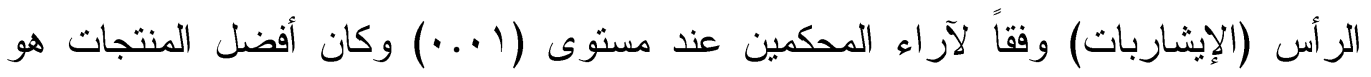

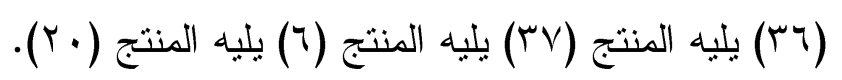

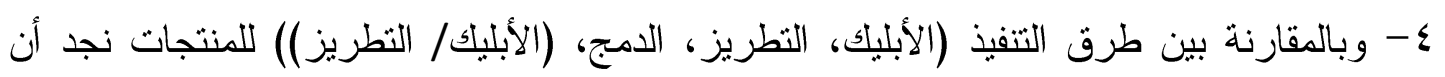

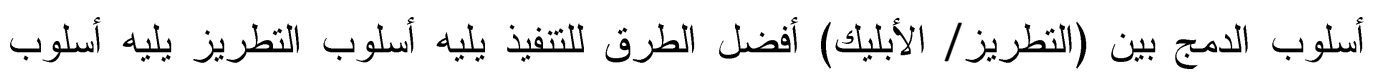
الأبليك.

0- جاءت أفضل المنتجات المنفذة هو المنتج (بَ) و المنفذ بأسلوب الدمج بين (الأبليك/ التطريز)

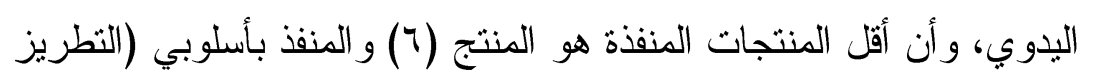

التوصيات :

ا- الإهتمام بالزخارف الطبيعية ودر اسة النواحي الفنية و الجمالية لأنو اعها المختلفة و الإستفادة منها

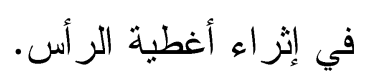

r- الإستفادة من القيم الوظيفية و الجمالية لبقايا الأقششة في إثراء أغطية الر أس.

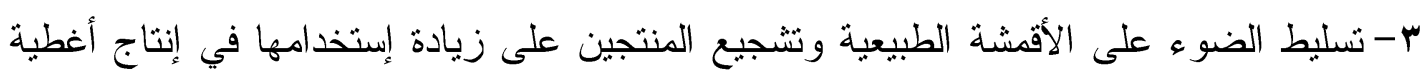
الر أس لما لها من فو ائد صحية ووظيفية. ع - الإهنمام بكل ما هو جديد في فن (النطريز اليدوي - التطريز الآلي - الأبليك).

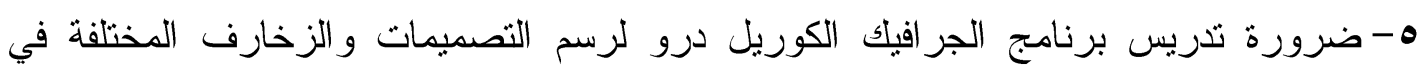
المعاهد و الكليات المتخصصة. 


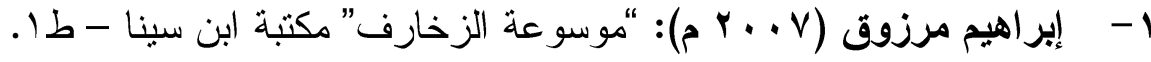

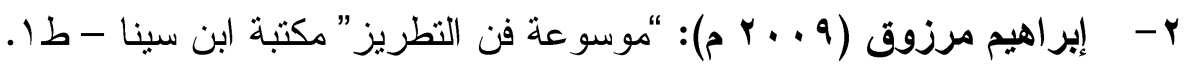

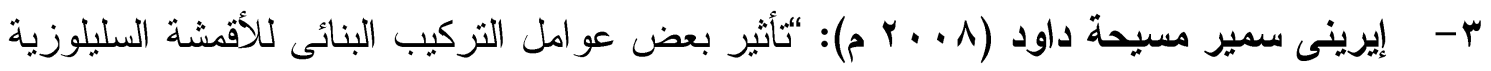
المصبوغة بالصبغات الطبيعية على خواص الأداء الوظيفى لأغطية الر أس” المؤتمر العربي ملي لئي الثاني عشر للإقتصاد المنزلي - جامعة المنوفية - (1) - 9 - (1) أغسطس.

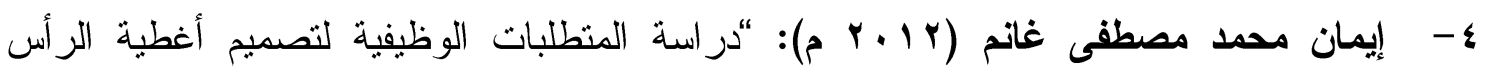
للسيدات" رسالة ماجسنير غير منشورة - كلية الفنون التطبيقية - جامعة حلوان.

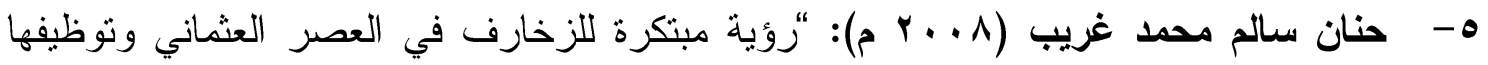
لإثر اء أغطية الرأس للنساء" رسالة ماجستير غير منشورة - كلية الإقتصاد المنزلي - جامعة حلوان.

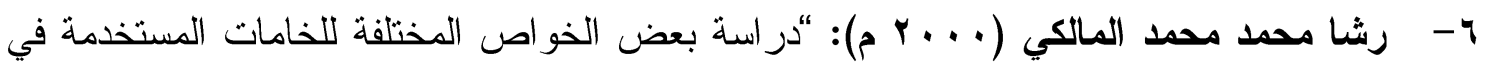

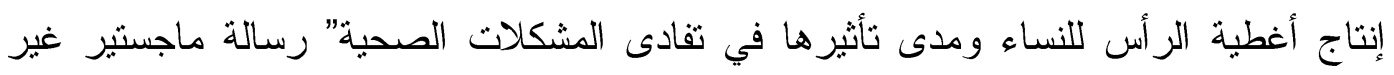
منشورة - كلية الإقتصاد المنزلي - جامعة المنوفية.

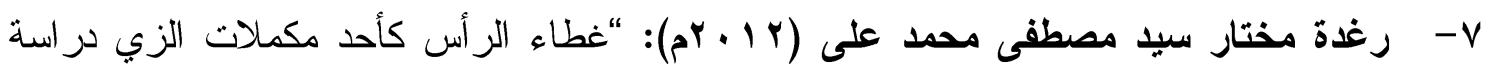

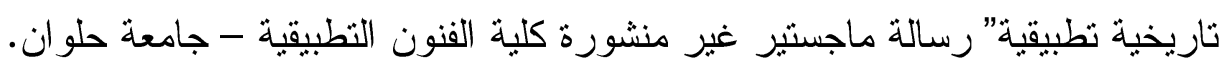

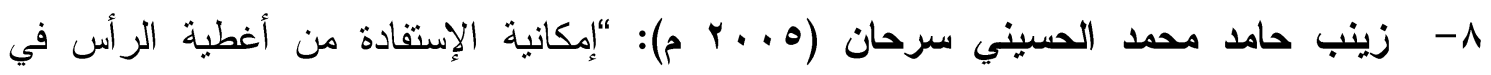
العصور الإسلامية في إبتكار تصميمات عصرية لطالبات الجامعة" رسالة ماجستير غير منشورة - جامعة المنوفية - كلية الإقتصاد المنزلي.

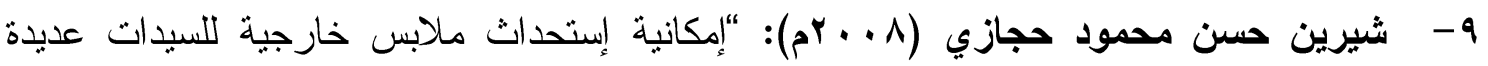
الأغر اض لخدمة الناحية الجمالية والاقتصادية" رسالة ماجستير غير منشورة - كلية التربية النو عية - جامعة المنصورة. • 1 - عفاف كمال على محمود ( . . . . م م): “إمكانبة الحصول على تأثثر ات جمالية ووظيفية جديدة مستوحاة من الفنون الحديثة بإستخدام بقايا الأقمشة لمنتجات الأطفال" رسالة ماجستير غير منشورة - كلية الإقتصاد المنزلي - جامعة المنوفية.

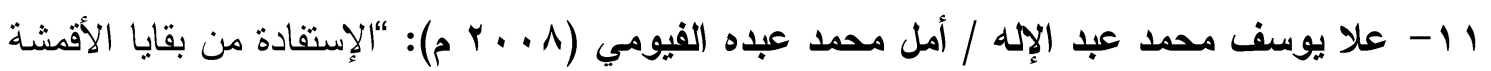
و الإيشاربات الغير مسايرة للموضة في إثراء جماليات الطرح بإستخدام ثقنيات مختلفة لخدمة

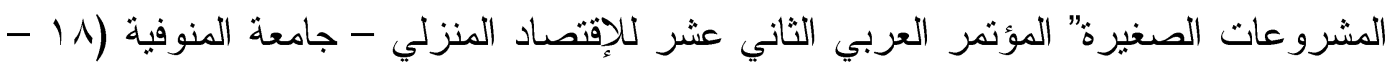
. r ا - علياء يحيى مبروك يحيى (ع . r م): “در اسة لأغطية الر أس للمر أة في بعض مناطق بالمملكة

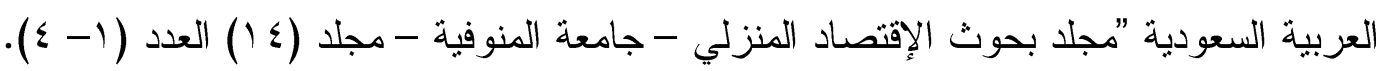


r ا - علية عابدين / زينب الدباغ (r . . rم): “در اسات في النسيج وأسس تتفيذ الملابس” دار الفكر

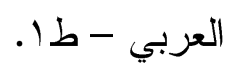

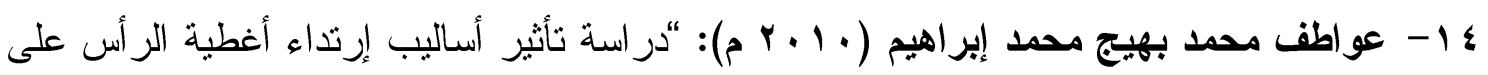

صحة المر أة" المؤتمر العربي الر ابع عشر للإقتصاد المنزلي - جامعة المنوفية (ب-r) نوفمبر.

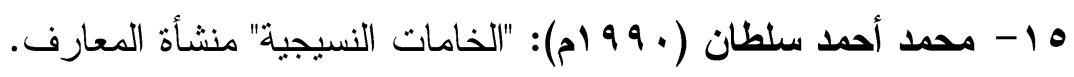

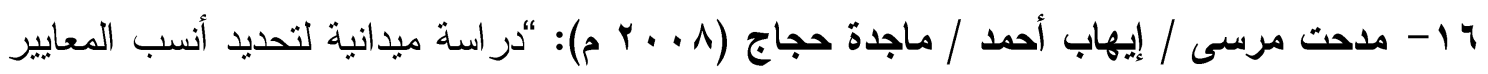
الخاصة بحجاب الفتاة الجامعية لإنتقاء أفضلها للشر اء أو الإستخدام” المؤتمر العربي الثاني عشر مراه

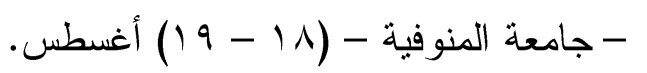

V - نادية محمود خليل (999 19): “مكملات الملابس - الإكسسوار فن الأناقة و الجمال” دار الفكر

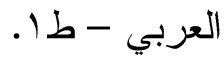

1 - يسرى معوض عيسى أحمد (V . . . م م): "عنصر النبات كمصدر لإثر اء التصميمات الزخرفية و الإستفادة منها في تصميم أغطية الر أس" مجلد بحوث الإقتصاد المنزلي - جامعة المنوفية - لئل

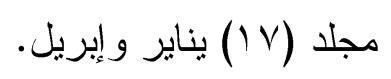

\section{ثانياً: المراجع الأجنبية:}

19- Joseph Marjory (1980): "Fabriccare and laundry products of textiles" third Edition, P.68.

20- Lesleil, Nacy, Merry Jo, Barbare, and Janet (1990): Dermatological health problem attributed by customer to contact with textiles"Home economics research journal vol. 18, no 4, P.311: 322.

21- Shfik, A. (1993): "polyester but not cotton or wool textiles inhibit hair growth" Dermatology (4), P.42: 239. 